\title{
Poly(methimazolyl)borato Nitrosyl Complexes of Molybdenum and Tungsten
}

\author{
Robyn J. Abernethy, Mark R. St.-J. Foreman, Anthony F. Hill,* Never Tshabang, \\ Anthony C. Willis, and Rowan D. Young \\ Research School of Chemistry, Institute of Advanced Studies, Australian National University, Canberra, \\ Australian Capital Territory, Australia
}

Received May 8, 2008

\begin{abstract}
The syntheses of a range of poly(methimazolyl)borate -ligated nitrosyl complexes of tungsten and molybdenum are reported, the characterization of which includes the crystal structure determinations of the compounds [W(NO) $\left.(\mathrm{CO})_{2}\left\{\kappa^{3}-S, S^{\prime}, S^{\prime \prime}-\mathrm{HB}(\mathrm{mt})_{3}\right\}\right]$, [W(NO) $\left.(\mathrm{CO})_{2}\left(\mathrm{PPh}_{3}\right)\left\{\kappa^{2}-S, S^{\prime}-\mathrm{H}_{2} \mathrm{~B}(\mathrm{mt})_{2}\right\}\right]$, and [Mo(NO)$\left.(\mathrm{CO})_{2}\left\{\kappa^{3}-H, S, S^{\prime}-\mathrm{H}_{2} \mathrm{~B}(\mathrm{mt})_{2}\right\}\right]$ (mt = methimazoyl). The reaction of $\left[\mathrm{W}(\mathrm{NO})(\mathrm{CO})_{3}\left(\mathrm{PPh}_{3}\right)_{2}\right] \mathrm{PF}_{6}$ with $\mathrm{Na}\left[\mathrm{HB}(\mathrm{mtt})_{3}\right]$ and $\mathrm{Na}\left[\mathrm{H}_{2} \mathrm{~B}(\mathrm{mt})_{2}\right]$ provides respectively $\left[\mathrm{W}(\mathrm{NO})(\mathrm{CO})_{2}\left\{\mathrm{HB}(\mathrm{mt})_{3}\right\}\right]$ and $\left[\mathrm{W}(\mathrm{NO})(\mathrm{CO})_{2}\left(\mathrm{PPh}_{3}\right)\left\{\kappa^{2}-\right.\right.$ $\left.\left.S, S^{\prime}-\mathrm{H}_{2} \mathrm{~B}(\mathrm{mt})_{2}\right\}\right]$. The complexes $\left[\mathrm{M}(\mathrm{NO})(\mathrm{CO})_{2}\left\{\mathrm{HB}(\mathrm{mt})_{3}\right\}\right]$ and $\left[\mathrm{M}(\mathrm{NO})(\mathrm{CO})_{2}\left\{\kappa^{3}-H, S, S^{\prime}-\mathrm{H}_{2} \mathrm{~B}(\mathrm{mt})_{2}\right\}\right](\mathrm{M}$ $=\mathrm{W}, \mathrm{Mo}$ ) arise from the reactions of $\mathrm{Na}\left[\mathrm{M}(\mathrm{CO})_{3}\left\{\mathrm{H}_{2} \mathrm{~B}(\mathrm{mt})_{2}\right\}\right]$ with $N$-methyl- $N$-nitrosotoluenesulfonamide. The molybdenum complex $\left[\mathrm{Mo}(\mathrm{NO})(\mathrm{CO})_{2}\left\{\mathrm{HB}(\mathrm{mt})_{3}\right\}\right]$ is also obtained unexpectedly from the reaction of $\left[\mathrm{Mo}\left(\eta^{3}-\mathrm{C}_{3} \mathrm{H}_{5}\right)(\mathrm{CO})_{2}\left\{\mathrm{HB}(\mathrm{mt})_{3}\right\}\right]$ with $\left[\mathrm{NO} \mathrm{BF}_{4}\right.$.
\end{abstract}

\section{Introduction}

A vast amount of chemistry has been described that is based on tris(pyrazolyl)borato nitrosyl complexes of tungsten and molybdenum, ${ }^{1}$ all of which derives from the complexes $\left[\mathrm{M}(\mathrm{NO})(\mathrm{CO})_{2}\left(\mathrm{Tp}^{\mathrm{x}}\right)\right]\left(\mathrm{Tp}^{\mathrm{x}}=\mathrm{HB}(\mathrm{pz})_{3}, \mathrm{HB}\left(\mathrm{pzMe}_{2}\right)_{3}, \mathrm{pz}=\right.$ pyrazol-1-yl, pzMe ${ }_{2}=3,5$-dimethylpyrazol-1-yl, $\mathrm{M}=\mathrm{Mo}$, W) described in Trofimenko's seminal report. ${ }^{2}$ Much of the utility of these complexes lies in their oxidative decarbonylation by halogens to provide the complexes $\left[\mathrm{M}(\mathrm{NO}) \mathrm{X}_{2}\left(\mathrm{Tp}^{\mathrm{x}}\right)\right](\mathrm{X}=\mathrm{Br}$, $\mathrm{I}$ ), the halides of which are readily replaced by a wide range of chalcogen- and nitrogen-based nucleophiles. ${ }^{3}$ Given that reactions of these dihalide complexes with carbon-based nucleophiles have generally been unsuccessful, ${ }^{4}$ these complexes have held little relevance in an organometallic context, until comparatively recently. In a series of papers, ${ }^{5}$ Harman has demonstrated that sequential reduction of the dihalides in the presence of a suitable spectator ligand $\left(\mathrm{L}=\mathrm{PMe}_{3}, \mathrm{NIm}=N\right.$-methylimidazole) and a variety of unsaturated organic substrates provides a remarkable scaffold upon which to execute often unique functionalizations, a number of which rely on the effective dearomatization of arenes and heteroarenes. The spectacular performance of the "M(NO)(L)\{HB(pz $\left.)_{3}\right\} "\left(\mathrm{~L}=\mathrm{PMe}_{3}, \mathrm{NIm}\right)$ scaffold in such processes originates from a combination of factors that includes (i) the modest steric profile of the $\left(\mathrm{HB}(\mathrm{pz})_{3}\right)(\mathrm{NO})(\mathrm{L})$ ligand set $\left(\mathrm{cf} . \mathrm{Tp}^{\mathrm{x}}=\mathrm{HB}\left(\mathrm{pzMe}_{2}\right)_{3}\right)$, (ii) the "octahedral enforcer" character of tris(pyrazolyl)borates which somewhat disfavors the seven-coordinate geometry that would result from oxidative addition reactions, e.g., $\mathrm{C}-\mathrm{H}$ activation, but, most importantly, (iii) the strong $\sigma$-basicity coupled with the absence of any effective $\pi$-acidity on the part of the coligands $\mathrm{HB}(\mathrm{pz})_{3}$ and $\mathrm{L}$ such that the $\pi$-system of the

* To whom correspondence should be addressed. E-mail: a.hill@ anu.edu.au.

(1) Trofimenko, S. Scorpionates: The Coordination of Polypyrazolylborate Ligands; Imperial College Press: London, 1999.

(2) Trofimenko, S. Inorg. Chem. 1969, 8, 2675.

(3) McCleverty, J. A. Inorg. Chim. Acta 1982, 62, 67.

(4) Briggs, T. N.; Jones, C. J.; McCleverty, J. A.; Neaves, B. D.; El Murr, N.; Colquhoun, H. M. J. Chem. Soc., Dalton Trans. 1985, 1249.
Chart 1. $\kappa^{2}-S, S^{\prime}$-Dihydrobis(methimazolyl)borato (a), $\kappa^{3}-H, S, S^{\prime}-$ Dihydrobis(methimazolyl)borato (b), $\kappa^{3}-S, S^{\prime}, S^{\prime \prime}$ - Hydrotris(methimazolyl)borato (c), and $\kappa^{4}-B, S, S^{\prime}, S^{\prime \prime}$-Tris(methimazolyl)borane (d, "Metallaboratrane") Complexes<smiles>C=CN(C)CSC1N(C)C=CN1C</smiles>

(a)<smiles>[Y19]C1(CS)SSC[R5]1([H])[H]</smiles>

(c)

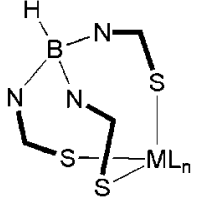

(b)<smiles>C1NC2CC(N1)SCN2</smiles>

(d)

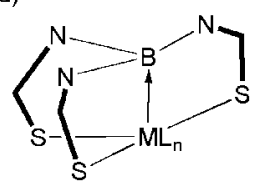

unsaturated substrate provides the only mechanism for alleviating the superlative $\pi$-basicity of the single $t_{2 g}$-type orbital not involved in nitrosyl binding.

We have previously collated infrared data $\left(v_{\mathrm{CO}}, k_{\mathrm{CO}}\right)$ for a wide range of alkylidyne complexes of the form $\left[\mathrm{W}\left(\equiv \mathrm{CC}_{6} \mathrm{H}_{4} \mathrm{Me}-\right.\right.$ 4) $\left.(\mathrm{CO})_{2}\left(\mathrm{~L}^{\prime}\right)\right],{ }^{6}$ wherein $\mathrm{L}^{\prime}$ is a facially tridentate neutral, anionic, or dianionic ligand, including $\mathrm{HB}(\mathrm{pz})_{3}, \mathrm{HB}\left(\mathrm{pzMe}_{2}\right)_{3}$, and Reglinski's tris(methimazolyl)borate $\mathrm{HB}(\mathrm{mt})_{3}(\mathrm{mt}=$ "methimazolyl", 2-mercapto-3-methylimidazolide). ${ }^{7}$ Among complexes of monoanionic capping ligands, the complex $\left[\mathrm{W}\left(=\mathrm{CC}_{6} \mathrm{H}_{4} \mathrm{Me}-\right.\right.$ 4) $\left.(\mathrm{CO})_{2}\left\{\mathrm{HB}(\mathrm{mt})_{3}\right\}\right]$ displayed exceptionally low values for $v_{\mathrm{CO}}$ and $k_{\mathrm{CO}}$ (surpassed only by the complex of Kläui's tripodal ligand $\left.\mathrm{CpCo}\left(\mathrm{PO}_{3} \mathrm{Et}_{2}\right)_{3}\right),{ }^{8}$ indicating that the $\mathrm{HB}(\mathrm{mt})_{3}$ ligand is especially effective in raising the $\pi$-basicity of a metal center. Given (i) the importance of metal $\pi$-basicity in the chemistry pioneered by Harman and (ii) the isoelectronic relationship between three-electron-donor nitrosyl and alkylidyne ligands, we have now turned our attention to developing synthetic routes 
Scheme 1. Synthesis of Hydrotris(methimazolyl)borato Nitrosyl Complexes ${ }^{a}$

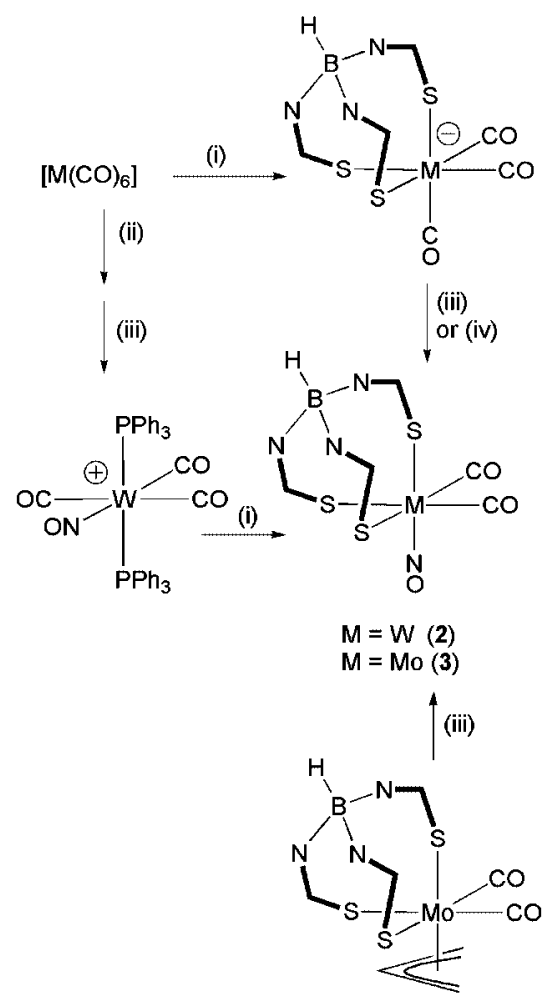

${ }^{a}$ Legend (i) $\mathrm{Na}\left[\mathrm{HB}(\mathrm{mt})_{3}\right]$; (ii) $\mathrm{NaBH}_{4}, \mathrm{PPh}_{3}$; (iii) $[\mathrm{NO}] \mathrm{BF}_{4}$ or [NO]PF 6 ; (iv) ${ }^{n} \mathrm{BuONO}$ or $\mathrm{ONNMeSO}_{2} \mathrm{C}_{6} \mathrm{H}_{4} \mathrm{Me}-4$ (Diazald).

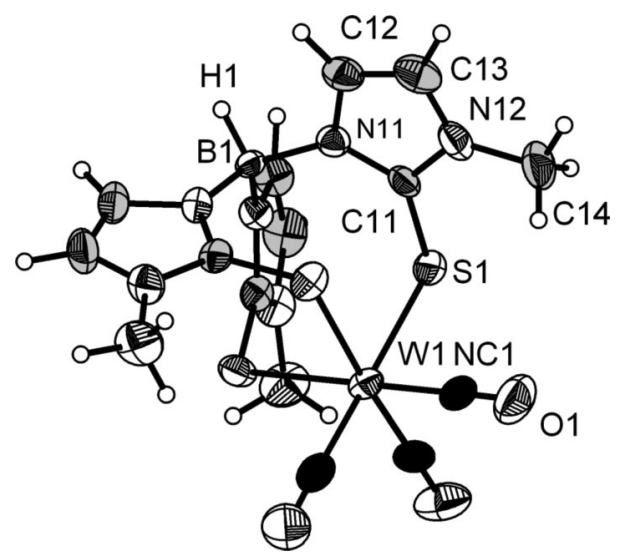

Figure 1. Molecular geometry of $\mathbf{2}$ in the crystal state (heteroatoms in white, carbon atoms in light gray, pseudo atoms $\mathrm{NC} 1\left(={ }^{1} / 3 \mathrm{~N}+\right.$ $2 /{ }_{3} \mathrm{C}$ ) in dark gray, $50 \%$ displacement ellipsoids). One of the two crystallographically independent but similar molecules is shown. Selected bond lengths $(\AA)$ and angles $(\mathrm{deg})$ : $\mathrm{W} 1-\mathrm{S} 1=2.5670(13)$, $\mathrm{W} 1-\mathrm{NC} 1=1.915(5), \mathrm{S} 1-\mathrm{C} 11=1.726(4), \mathrm{O} 1-\mathrm{NC} 1=1.164(6)$, $\mathrm{N} 11-\mathrm{B} 1=1.535(4), \mathrm{N} 12-\mathrm{C} 11=1.347(6), \mathrm{N} 12-\mathrm{C} 13=1.369(7)$, $\mathrm{N} 12-\mathrm{C} 14=1.468(6) ; \mathrm{S} 1-\mathrm{W} 1-\mathrm{S} 1 *=89.90(4), \mathrm{W} 1-\mathrm{NC} 1=$ 92.29(15), $\mathrm{S} 1-\mathrm{W} 1-\mathrm{NC} 1 *=176.59(15), \mathrm{NC} 1-\mathrm{W} 1-\mathrm{NC} 1 *=$ 90.42(19), W1-S1-C11 = 104.85(14), S1-W1-NC1 = 92.29(15) (asterisk indicates symmetry-generated counterpart). See Figure S1 (Supporting Information) for an alternative view.

to the complexes $\left[\mathrm{M}(\mathrm{NO})(\mathrm{CO})_{2}\left\{\mathrm{H}_{x} \mathrm{~B}(\mathrm{mt})_{4-x}\right\}\right](x=1,2 ; \mathrm{M}=$ $\mathrm{Mo}, \mathrm{W})$. Furthermore, although nitrosyl bis(pyrazolyl)borate complexes of molybdenum and tungsten remain unknown, we have also explored the synthesis of nitrosyl complexes of these metals ligated by the bis(methimazolyl) borate ligand, mindful that it may serve as a bi- or tridentate ligand, the latter coordination mode (Chart 1b) via a three-center, two-electron $\mathrm{B}-\mathrm{H}-\mathrm{M}$ interaction. ${ }^{9}$ Since the completion of these studies, ${ }^{10}$ the syntheses of the complexes $\left[\mathrm{M}(\mathrm{NO})(\mathrm{CO})_{2}\left\{\mathrm{HB}(\mathrm{mt})_{3}\right\}\right](\mathrm{M}$ $=\mathrm{Mo}, \mathrm{W})$ have been described by Reglinski and Spicer, ${ }^{11}$ albeit in disappointing yields (ca. 15\%) that have so far rendered these complexes unattractive for further study.

\section{Results and Discussion}

Hydrotris(methimazolyl)borate Complexes. The salt mer, trans $-\left[\mathrm{W}(\mathrm{NO})(\mathrm{CO})_{3}\left(\mathrm{PPh}_{3}\right)_{2}\right] \mathrm{PF}_{6}\left(\mathbf{1}-\mathbf{P F}_{\mathbf{6}}\right)$ described by Hillhouse was chosen as a substrate for the introduction of bis- and tris(methimazolyl)borate ligands, due to the demonstrated lability of one carbonyl ligand, its straightforward and high-yield

(5) (a) Todd, M. A.; Sabat, M.; Myers, W. H.; Harman, W. D. J. Am. Chem. Soc. 2007, 129, 11010. (b) Liu, W.; Welch, K.; Trindle, C. O.; Sabat, M.; Myers, W. H.; Harman, W. D. Organometallics 2007, 26, 2589. (c) Welch, K. D.; Harrison, D. P.; Lis, E. C., Jr.; Liu, W.; Salomon, R. J.; Harman, W. D.; Myers, W. H. Organometallics 2007, 26, 2791. (d) Delafuente, D. A.; Kosturko, G. W.; Graham, P. M.; Harman, W. H.; Myers, W. H.; Surendranath, Y.; Klet, R. C.; Welch, K. D.; Trindle, C. O.; Sabat, M.; Harman, W. D. J. Am. Chem. Soc. 2007, 129, 406. (e) Surendranath, Y.; Welch, K. D.; Nash, B. W.; Harman, W. H.; Myers, W. H.; Harman, W. D. Organometallics 2006, 25, 5852. (f) Welch, K. D.; Smith, P. L.; Keller, A. P.; Myers, W. H.; Sabat, M.; Harman, W. D. Organometallics 2006, 25, 5067. (g) Lis, E. C., Jr.; Delafuente, D. A.; Lin, Y.; Mocella, C. J.; Todd, M. A.; Liu, W.; Sabat, M.; Myers, W. H.; Harman, W. D. Organometallics 2006, 25, 5051. (h) Ha, Y.; Dilsky, S.; Graham, P. M.; Liu, W.; Reichart, T. M.; Sabat, M.; Keane, J. M.; Harman, W. D. Organometallics 2006, 25, 5184. (i) Todd, M. A.; Grachan, M. L.; Sabat, M.; Myers, W., H.; Harman, W. D. Organometallics 2006, 25, 3948. (j) Bassett, K. C.; You, F.; Graham, P. M.; Myers, W. H.; Sabat, M.; Harman, W. D. Organometallics 2006, 25, 435. (k) Liu, W.; You, F.; Mocella, C. J.; Harman, W. D. J. Am. Chem. Soc. 2006, 128, 1426. (1) Myers, W. H.; Welch, K. D.; Graham, P. M.; Keller, A.; Sabat, M.; Trindle, C. O.; Harman, W. D. Organometallics 2005, 24, 5267. (m) Keane, J. M.; Harman, W. D. Organometallics 2005, 24, 1786. (n) Delafuente, D. A.; Myers, W. H.; Sabat, M.; Harman, W. D. Organometallics 2005, 24, 1876. (o) Graham, P. M.; Mocella, C. J.; Sabat, M.; Harman, W. D. Organometallics 2005, 24, 911. (p) Smith, P. L.; Keane, J. M.; Shankman, S. E.; Chordia, M. D.; Harman, W. D. J. Am. Chem. Soc. 2004, 126, 15543. (q) Ding, F.; Harman, W. D. J. Am. Chem. Soc. 2004, 126, 13752. (r) Mocella, C. J.; Delafuente, D. A.; Keane, J. M.; Warner, G. R.; Friedman, L. A.; Sabat, M.; Harman, W. D. Organometallics 2004, 23, 3772. (s) Graham, P. M.; Meiere, S. H.; Sabat, M.; Harman, W. D. Organometallics 2003, 22, 4364. (t) Meiere, S. H.; Keane, J. M.; Gunnoe, T. B.; Sabat, M.; Harman, W. D. J. Am. Chem. Soc. 2003, 125, 2024.

(6) Foreman, M. R. St.-J.; Hill, A. F.; White, A. J. P.; Williams, D. J. Organometallics 2003, 22, 3831.

(7) Garner, M.; Reglinski, J.; Cassidy, I.; Spicer, M. D.; Kennedy, A. R. J. Chem. Soc., Chem. Commun. 1996, 1975.

(8) Kläui, W.; Hamers, H. J. Organomet. Chem. 1988, 345, 287.

(9) (a) Foreman, M. R. St.-J.; Hill, A. F.; Tshabang, N.; White, A. J. P.; Williams, D. J. Organometallics 2003, 22, 5593. (b) Crossley, I. R.; Hill, A. F.; Willis, A. C. Organometallics 2005, 24, 4889. (c) Crossley, I. R.; Hill, A. F.; Humphrey, E. R.; Smith, M. K. Organometallics 2006, 25, 2242. (d) Hill, A. F.; Smith, M. K. Organometallics 2008, 27, 2137. (e) Kimblin, C.; Hascall, T.; Parkin, G. Inorg. Chem. 1997, 36, 5680. (f) Kimblin, C.; Bridgewater, B. M.; Hascall, T.; Parkin, G. Dalton Trans. 2000, 891. (g) Kimblin, C.; Churchill, D. G.; Bridgewater, B. M.; Girard, J. N.; Quarless, D. A.; Parkin, G. Polyhedron 2001, 20, 1891. (h) Philson, L. A.; Alyounes, D. M.; Zakharov, L. N.; Rheingold, A. L.; Rabinovich, D. Polyhedron 2003, 22, 3461. (i) Graham, L. A.; Fout, A. R.; Kuehne, K. R.; White, J. L.; Mookherji, B.; Marks, F. M.; Yap, G. P. A.; Zakharov, L. N.; Rheingold, A. L.; Rabinovich, D. Dalton Trans. 2005, 171. (j) Alvarez, H. M.; Tanski, J. M.; Rabinovich, D. Polyhedron 2004, 23, 395. (k) Alvarez, H. M.; Krawiec, M.; Donovan-Merkert, B. T.; Fouzi, M.; Rabinovich, D. Inorg. Chem. 2001, 40, 5736. (1) Cammi, R.; Lanfranchi, M.; Marchio, L.; Mora, C.; Paiola, C.; Pellinghelli, M. A. Inorg. Chem. 2003, 42, 1769. (m) Kuan, S. L.; Leong, W. K.; Goh, L. Y.; Webster, R. D. J. Organomet. Chem. 2006, 691, 907. (n) Wang, Y.-L.; Cao, R.; Bi, W.-H. Polyhedron 2005, 24, 585. (o) Dodds, C. A.; Garner, M.; Reglinski, J.; Spicer, M. D. Inorg. Chem. 2006, 2733. (p) Bailey, P. J.; Lorono-Gonzales, D. J.; McCormack, C.; Parsons, S.; Price, M. Inorg. Chim. Acta 2003, 354, 61.

(10) Tshabang, N. The Chemistry of Poly(methimazolyl)borate Complexes Ph.D. Thesis, Australian National University, 2005.

(11) Schwalbe, M.; Andrikoupoulos, P. C.; Armstrong, D. R.; Reglinski, J.; Spicer, M. D. Eur. J. Inorg. Chem. 2007, 1351. 
synthesis and its thermal and aerobic stability, ${ }^{12}$ thereby avoiding the intermediacy of air-sensitive species. Heating a mixture of 1-PF 6 and $\mathrm{Na}\left[\mathrm{HB}(\mathrm{mt})_{3}\right]^{7,13}$ in dichloromethane for $24 \mathrm{~h}$ under reflux provided the orange complex $\left[\mathrm{W}(\mathrm{NO})(\mathrm{CO})_{2}\left\{\mathrm{HB}(\mathrm{mt})_{3}\right\}\right]$ (2) in $75 \%$ yield (Scheme 1). The complex was obtained previously in low yield, inter alia, from the reaction of $\mathrm{Na}\left[\mathrm{HB}(\mathrm{mt})_{3}\right]$ with $\left[\mathrm{W}(\mathrm{CO})_{6}\right]$ in refluxing dmf followed by nitrosylation with $[\mathrm{NO}] \mathrm{BF}_{4}{ }^{11}$ While the present synthesis is multistep and is far from atom efficient, the yields are reproducibly high with minimal attendant purification issues. Alternatively, it was found that the reaction of $\mathrm{Na}\left[\mathrm{W}(\mathrm{CO})_{3}\right.$ $\left.\left\{\mathrm{HB}(\mathrm{mt})_{3}\right\}\right]$ (formed in situ in refluxing acetonitrile) with $N$-methyl- $N$-nitroso-4-toluenesulfonamide (Diazald) provided moderate yields of $\mathbf{2}$, which precipitates from acetonitrile in high purity, with further material available from the filtrate. It is worth noting that this sequence does not most likely proceed via formation of $\left[\mathrm{W}(\mathrm{NCMe})_{3}(\mathrm{CO})_{3}\right]$, because the complete conversion of $\left[\mathrm{W}(\mathrm{CO})_{6}\right]$ to $\left[\mathrm{W}(\mathrm{NCMe})_{3}(\mathrm{CO})_{3}\right]$ typically requires 4-6 days in refluxing acetonitrile. Since the formation of $\mathrm{Na}\left[\mathrm{W}(\mathrm{CO})_{3}\left\{\mathrm{HB}(\mathrm{mt})_{3}\right\}\right]$ is effectively complete after $18 \mathrm{~h}$ at reflux, we may assume that the chelate effect plays a role in accelerating the formation of the desired tricarbonylmetalate. The infrared spectrum of $\mathbf{2}$ in dichloromethane solution shows two carbonyl absorptions (1993 and $1893 \mathrm{~cm}^{-1}$ ) and one nitrosyl absorption (1622 $\mathrm{cm}^{-1}$ ). Table S1 (Supporting Information) presents infrared data for a selection of complexes of the form $\left[\mathrm{M}(\mathrm{NO})(\mathrm{CO})_{2}(\mathrm{~L})\right],{ }^{2,14,15}$ where $\mathrm{L}$ is an anionic facially tridentate ligand, and illustrates that $\mathrm{HB}(\mathrm{mt})_{3}$ is a potent net donor relative to these more familiar ligands, an inference supported by the theoretical studies of Reglinski and Spicer. ${ }^{11}$ Similar conclusions have been inferred from data for the complexes $\left[\mathrm{W}\left(\equiv \mathrm{CC}_{6} \mathrm{H}_{4} \mathrm{Me}-\right.\right.$ 4) $\left.(\mathrm{CO})_{2}(\mathrm{~L})\right]^{6}$ and $\left[\mathrm{Mo}\left(\eta^{3}-\mathrm{C}_{3} \mathrm{H}_{5}\right)(\mathrm{CO})_{2}(\mathrm{~L})\right] .{ }^{16}$ The use of the "M(NO) $(\mathrm{CO})_{2}$ " unit as a spectroscopic reporter is perhaps more desirable, not only because two parameters are provided $\left(k_{\mathrm{CO}}\right.$ and $v_{\mathrm{NO}}$ ) but also because the alkylidyne series is in part dependent on the alkylidyne substituent while the allyl series is complicated by the possibility of endo-exo isomerism.

The gross molecular composition of $\mathbf{2}$ was confirmed by elemental microanalysis and supported by APCI mass spectroscopy, which revealed peaks attributable to $[\mathrm{M}-\mathrm{CO}-$ $\mathrm{NO}^{+}\left(\mathrm{m} / \mathrm{z}\right.$ 565.1) and $[\mathrm{M}-\mathrm{NO}-2 \mathrm{CO}]^{+}(\mathrm{m} / \mathrm{z} 533.1)$. Although the molecular ion was not observed under these conditions, a peak corresponding to $[\mathrm{M}+\mathrm{Na}]^{+}$was observed in the ESI mass spectrum. The $\mathrm{HB}(\mathrm{mt})_{3}$ ligand is apparent in the ${ }^{1} \mathrm{H}$ NMR spectrum measured in $\mathrm{CD}_{2} \mathrm{Cl}_{2}$, giving rise to singlets at $\delta 3.66$ and 3.70 ppm for the $\mathrm{NCH}_{3}$ groups, indicating two chemical environments (ratio 1:2), further supported by $\mathrm{NHC}=\mathrm{CHN}$ resonances appearing as two sets of doublets at $\delta$ 6.84, 6.88 and $\delta 6.90,6.92 \mathrm{ppm}$. Notably, Reglinski and Spicer observed three distinct methimazolyl environments for spectra measured in $d_{6}$-DMSO. The molecule, as formulated, is chiral and should therefore indeed give rise to three distinct chemical environments for the mt groups. That two of the three groups appear chemically equivalent on the ${ }^{1} \mathrm{H}$ NMR time scale might be taken as indicative of fluxional processes involving site exchange between two $\mathrm{mt}$ environments or, alternatively,

(12) Hillhouse, G. L.; Haymore, B. L. Inorg. Chem. 1987, 26, 1876

(13) Hill, A. F.; Owen, G. R.; White, A. J. P.; Williams, D. J. Angew. Chem., Int. Ed. 1999, 38, 2759.

(14) Malito, J. T.; Shakir, R.; Arwood, J. L. J. Chem. Soc., Dalton Trans. 1980, 1253.

(15) Legzdins, P.; Reina, R.; Shaw, M. J. Organometallics 1993, 12, 1029.

(16) Garner, M.; Lehmann, M.-A.; Reglinski, J.; Spicer, M. D. Organometallics 2001, 20, 5233.
Table 1. Infrared Data for the Complexes [W(L)(CO) $\left.)_{2}\left\{\mathrm{HB}(\mathrm{mt})_{3}\right\}\right]$

\begin{tabular}{lrc}
\hline \multicolumn{1}{c}{$\mathrm{L}$} & $v_{\mathrm{CO}}\left(\mathrm{cm}^{-1}\right)$ & $k_{\mathrm{CO}}\left(\mathrm{N} \mathrm{cm}^{-1}\right)$ \\
\hline $\mathrm{NO}$ & 1993 & 15.26 \\
$\equiv \mathrm{CC} \equiv \mathrm{C}^{t} \mathrm{Bu}$ & 1893 & 15.05 \\
& 1975 & \\
$\equiv \mathrm{C}_{6} \mathrm{H}_{4} \mathrm{Me}$ & 1885 & 14.91 \\
$\equiv \mathrm{CN}^{\mathrm{i}} \operatorname{Pr}_{2}$ & 1967 & 14.19 \\
& 1875 &
\end{tabular}

accidental signal coincidence in $\mathrm{CD}_{2} \mathrm{Cl}_{2}$. Possible fluxional processes will be discussed in more detail below, alongside data for the corresponding molybdenum analogue, 3. The compound's formulation was further confirmed by a crystallographic study (Figure 1), the results of which are discussed below.

Two more and one less (vide infra) direct synthetic approaches were taken to prepare the molybdenum analogue $\left[\mathrm{Mo}(\mathrm{NO})(\mathrm{CO})_{2}\left\{\mathrm{HB}(\mathrm{mt})_{3}\right\}\right](3)$, relying on the substitution of molybdenum carbonyls being generally more facile than for those of tungsten. A mixture of $\left[\mathrm{Mo}(\mathrm{CO})_{6}\right]$ and $\mathrm{Na}\left[\mathrm{HB}(\mathrm{mt})_{3}\right]$ was heated under reflux in acetonitrile for $2 \mathrm{~h}$ under an $\mathrm{N}_{2}$ atmosphere to generate, in situ, the salt $\mathrm{Na}\left[\mathrm{Mo}(\mathrm{CO})_{3}\left\{\mathrm{HB}(\mathrm{mt})_{3}\right\}\right]{ }^{9 \mathrm{a}, 16}$ Treating the solution of $\mathrm{Na}\left[\mathrm{Mo}(\mathrm{CO})_{3}\left\{\mathrm{HB}(\mathrm{mt})_{3}\right\}\right]$ generated in situ with Diazald at room temperature provides the bright orange crystalline complex $\left[\mathrm{Mo}(\mathrm{NO})(\mathrm{CO})_{2}\left\{\mathrm{HB}(\mathrm{mt})_{3}\right\}\right](3)$. The moderate yields obtained $(46 \%)$ were compensated for by the expedience of a simple "one-pot" procedure that provides material of high purity without recourse to recrystallization. Diazald could be replaced as the nitrosylating agent by nitrosonium tetrafluoroborate to achieve a comparable yield. It has been reported that when a similar reaction was carried out in dmf, however, only low yields $(15 \%)$ were obtained. ${ }^{11}$ Alternatively, preisolated $\mathrm{Na}\left[\mathrm{Mo}(\mathrm{CO})_{3}\left\{\mathrm{HB}(\mathrm{mt})_{3}\right\}\right]^{9 \mathrm{a}}$ was treated with $n$-butyl nitrite in tetrahydrofuran. At room temperature, no reaction was observed; however, on heating to reflux, gas evolution ensued with formation of $\mathbf{3}$ in $53 \%$ yield. Spectroscopic data for $\mathbf{3}$ are directly comparable to those for $\mathbf{2}$ and call for little comment other than to note that, in contrast to 2, a molecular ion is readily discernible in the APCI and FAB mass spectra. The intrinsic chirality of the $\mathrm{HB}(\mathrm{mt})_{3} \mathrm{Mo}$ cage is manifested in the appearance in the ${ }^{13} \mathrm{C}\left\{{ }^{1} \mathrm{H}\right\}$ NMR spectrum of three distinct thione resonances $\left(\delta_{\mathrm{C}} 158.4,156.3,155.3\right)$ and resonances $\left(\delta_{\mathrm{C}} 222.5,226.9\right)$ for the diastereotopic carbonyl ligands. As noted above, similar behavior was apparent for the tungsten analogue 2 . Given that nitrosyl and alkylidyne ligands are each three-electron donors, the complexes $\left[\mathrm{M}(\mathrm{L})(\mathrm{CO})_{2}-\right.$ $\left.\left\{\mathrm{HB}(\mathrm{mt})_{3}\right\}\right](\mathrm{L}=\mathrm{NO}, \mathrm{CR})$ might be considered isoelectronic, albeit with the nitrosyl ligand being the more potent $\pi$-acid (Table 1). For the alkylidyne complexes $\left[\mathrm{W}(\equiv \mathrm{CR})(\mathrm{CO})_{2-}\right.$ $\left.\left\{\mathrm{HB}(\mathrm{mt})_{3}\right\}\right]$ the barrier to inversion of the $\mathrm{HB}(\mathrm{mt})_{3} \mathrm{~W}$ cage was found to be strongly dependent on the nature of the spatially remote alkylidyne substituent, the coalescence temperature decreasing with increasing $\pi$-basicity of the substituent ( $\mathrm{R}=$ $\left.\mathrm{N}^{i} \mathrm{Pr}_{2}<\mathrm{C}_{6} \mathrm{H}_{4} \mathrm{Me}<\mathrm{C} \equiv \mathrm{C}^{t} \mathrm{Bu}\right)$. This was taken to indicate a mechanism involving dissociation of one methimazolyl donor (trans to the strongly trans-labilizing alkylidyne) to provide a stereochemically nonrigid five-coordinate complex. In the case of $\mathbf{2}$ and $\mathbf{3}$ with the strongly $\pi$-acidic nitrosyl in place of the alkylidyne ligand, this would appear to support this interpretation in that, for $\mathbf{3}$, fluxionality is not evident in $d_{8}$-toluene until ca. $85{ }^{\circ} \mathrm{C}$ (broadening) and even at $100{ }^{\circ} \mathrm{C}$ (the safe practical temperature limit) complete coalescence is not achieved. Rather, one $\mathrm{N}-\mathrm{CH}_{3}$ resonance remains unique while the remaining two appear to closely approach coalescence (see the Experimental 


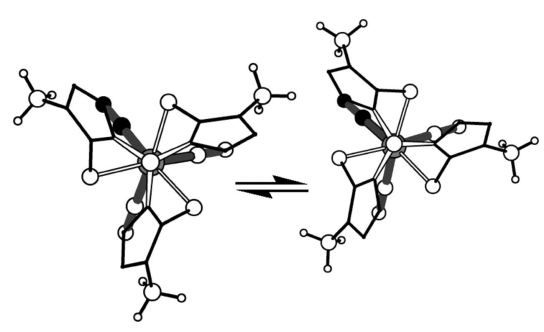

Figure 2. Cage inversion of $\mathrm{HB}(\mathrm{mt})_{3} \mathrm{M}(\mathrm{NO})(\mathrm{CO})_{2}$ ( $\mathrm{NO}$ in black, $\mathrm{CO}$ in white).

Section). Were this genuine coalescence, it would correspond to an activation energy of ca. $75 \mathrm{~kJ} \mathrm{~mol}^{-1}$ for the cage inversion process, comparable to that observed for $\left[\mathrm{ZnCl}\left\{\mathrm{HB}\left(\mathrm{mt}^{\mathrm{Bz}}\right)_{3}\right](65\right.$ $\mathrm{kJ} \mathrm{mol}^{-1} ; \mathrm{mt}^{\mathrm{Bz}}=2$-mercapto-1-benzylimidazolyl). ${ }^{18}$ For the alkylidyne complexes, coalescence of all three resonances was observed and so it would appear that distinct fluxional processes operate for the two classes of compounds. For $\mathbf{2}$ and $\mathbf{3}$ a twisting of the cage seems more likely, since even an octahedral Bailar twist $^{17}$ would leave all three $\mathrm{mt}$ environments inequivalent throughout the rotation. There is, however, a caveat that should be considered. Not only the peak shapes but also the chemical shifts for all three resonances show a marked temperature dependence, each moving ca. $0.5 \mathrm{ppm}$ downfield through the range $198-373 \mathrm{~K}$. It is therefore possible that two of the resonances are approaching coincidence rather than coalescence. This interpretation is supported by the observation that all three resonances show a comparable degree of line broadening. We are therefore inclined to suspect that this broadening may represent increased librational motion of the cage without actually reaching the $C_{3 v}$ transition state. That two crystallographically independent molecules are present in the crystal structure of $\mathbf{2}$ that vary only in just such a librational twist $\left(\theta^{\mathrm{m}}\right.$ $=47.30,41.33^{\circ}$; vide infra) would appear to provide further circumstantial supporting evidence.

Bailey has estimated ${ }^{18}$ that for the hypothetical complexes $\left[\mathrm{Mn}(\mathrm{CO})_{3}\left\{\mathrm{HB}\left(\mathrm{C}_{3} \mathrm{H}_{3} \mathrm{~N}_{2} \mathrm{~S}\right)_{3}\right\}\right]$ and $\left[\mathrm{ZnCl}\left\{\mathrm{HB}\left(\mathrm{C}_{3} \mathrm{H}_{3} \mathrm{~N}_{2} \mathrm{~S}\right)_{3}\right\}\right]$ the energy differences between the $C_{3}$ ground states and $C_{3 v}$ symmetric transition states for racemization would be 163 and $121 \mathrm{~kJ} \mathrm{~mol}^{-1}$, respectively. The latter is significantly lower than the former, presumably because the four-coordinate $\mathrm{d}^{10}$ center can more easily accommodate the flattening of the $\mathrm{ZnS}_{3}$ pyramid required to minimize strain in the $C_{3 v}$ transition state. Nevertheless, this value was approximately twice that observed experimentally $\left(60 \mathrm{~kJ} \mathrm{~mol}^{-1}\right)$, possibly suggesting the operation of a dissociative pathway. ${ }^{18}$ The real complex $\mathrm{d}^{6}-\left[\mathrm{Mn}(\mathrm{CO})_{3^{-}}\right.$ $\left.\left\{\mathrm{HB}\left(\mathrm{mt}^{\mathrm{Et}}\right)_{3}\right\}\right]\left(\mathrm{mt}^{\mathrm{Et}}=2\right.$-mercapto-1-ethylimidazolyl $)$ and the hypothetical complex $\left[\mathrm{Mn}(\mathrm{CO})_{3}\left\{\mathrm{HB}\left(\mathrm{C}_{3} \mathrm{H}_{3} \mathrm{~N}_{2} \mathrm{~S}\right)_{3}\right\}\right]$ are electronically more akin to $\mathrm{d}^{6}-\mathbf{2}$ and $\mathrm{d}^{6} \mathbf{- 3}$, and so the observation that the former does not undergo racemization up to the measured temperature limit $(373 \mathrm{~K})$ is consistent with the idea that $\mathrm{d}^{6}$ octahedral centers are typically substitution inert, disfavoring dissociative pathways. For $\mathbf{2}$ and $\mathbf{3}$ this is presumably also the case, but with a sufficiently low activation energy $\left(\Delta G^{\ddagger}(373\right.$ $\mathrm{K}) \approx 75 \mathrm{~kJ} \mathrm{~mol}^{-1}$ ) as to allow the concerted twist mechanism to operate (Figure 2).

(17) (a) Jordan, R. B. Reaction Mechanisms of Inorganic and Organometallic Systems; Oxford University Press: New York, 1991. (b) Wilkins, R. G. The Study of Kinetics and Mechanisms of Reactions of Transition Metal Complexes; Allyn and Bacon: Boston, 1974. (c) Meakin, P.; Trofimenko, S.; Jesson, J. P. J. Am. Chem. Soc. 1972, 94, 5677.

(18) Bailey, P. J.; Dawson, A.; McCormack, C.; Moggach, S. A.; Oswald, D. H.; Parsons, S.; Rankin, D. W. H.; Turner, A. Inorg. Chem. 2005, 44, 8884 .
Cationic molybdenum allyl nitrosyl complexes of the form $\left[\mathrm{Mo}(\mathrm{NO})(\mathrm{CO})\left(\eta^{3} \text {-allyl }\right)\left\{\mathrm{HB}(\mathrm{pz})_{3}\right\}\right]^{+}$are readily obtained via the reactions of allyl complexes $\left[\mathrm{Mo}(\mathrm{CO})_{2}\left(\eta^{3}\right.\right.$-allyl $\left.)\left\{\mathrm{HB}(\mathrm{pz})_{3}\right\}\right]$ with nitrosonium salts and have enjoyed considerable attention as intermediates in stoichiometric organic synthesis. ${ }^{19,20}$ Accordingly, the reaction of the allyl complex $\left[\mathrm{Mo}(\mathrm{CO})_{2}\left(\eta^{3}-\right.\right.$ $\left.\left.\mathrm{C}_{3} \mathrm{H}_{5}\right)\left\{\mathrm{HB}(\mathrm{mt})_{3}\right\}\right](4)^{16}$ with $\left[\mathrm{NO}^{16} \mathrm{BF}_{4}\right.$ in 1,2-dimethoxyethane $\left(-78\right.$ to $\left.0{ }^{\circ} \mathrm{C}\right)$ was explored and found to provide the nitrosyl complex $3(52 \%)$ rather than the anticipated salt [Mo(NO)$\left.(\mathrm{CO})\left(\eta^{3}-\mathrm{C}_{3} \mathrm{H}_{5}\right)\left\{\mathrm{HB}(\mathrm{mt})_{3}\right\}\right] \mathrm{BF}_{4}$. While this result was unexpected, it may be noted that nucleophilic (i.e., reductive) displacement of allyl ligands from molybdenum centers has precedent: e.g., the synthesis of $\left[\mathrm{Mo}(\mathrm{NCMe})_{2}(\mathrm{CO})_{2}\left(\mathrm{PPh}_{3}\right)_{2}\right]$ from $\left[\mathrm{MoCl}\left(\eta^{3}-\mathrm{C}_{3} \mathrm{H}_{5}\right)(\mathrm{NCMe})_{2}(\mathrm{CO})_{2}\right]$ and $\mathrm{PPh}_{3} \cdot{ }^{21}$ The nucleophile in the present case is presumably adventitious water or fluoride (from $\mathrm{BF}_{4}^{-}$), though the modest yield prevents us from excluding complex degradation (e.g., intermolecular hydride transfer from 4); the ultimate fate of the allyl ligand was not pursued. Of the various routes to $\mathbf{3}$ described above, the first employing Diazald is the most expedient; however, the respectable yields obtained with $\left[\mathrm{NO}_{\mathrm{BF}}\right.$ in acetonitrile are in contrast with those obtained by Reglinski and Spicer when the reaction was carried out in dmf. Thus, we might surmise that the propensity for the nitrosonium cation to act as a single-electron oxidant or hydride abstracting agent is reduced in acetonitrile, although $\mathrm{MeCN}$ and dmf have comparable dipole moments and dielectric constants.

Bis(methimazolyl)borate Complexes. While the $\mathrm{H}_{2} \mathrm{~B}(\mathrm{mt})_{2}$ ligand might appear superficially similar to the $\mathrm{H}_{2} \mathrm{~B}(\mathrm{pz})_{2}$ and $\mathrm{H}_{2} \mathrm{~B}(\mathrm{pzMe})_{2}$ ligands, the bridges between boron and a metal involve three $(\mathrm{N}, \mathrm{C}, \mathrm{S})$ rather than two $\left(\mathrm{N}, \mathrm{N}^{\prime}\right)$ atoms. This introduces geometric constraints that appear to favor the adoption of a tridentate $\kappa^{3}-H, S, S^{\prime}$ coordination mode (Chart 1b). ${ }^{9,22,23}$ Thus, complexes of this ligand featuring $\mathrm{B}-\mathrm{H}-\mathrm{M}$ interactions have been observed for a range of metals $(\mathrm{M}=\mathrm{Ti}$, Ta, Mo, Mn, Tc, Re, Ru, Rh, Co, Ni, Zn, Cd), ${ }^{9}$ including complexes wherein both $\kappa^{2}-S, S^{\prime}$ and $\kappa^{3}-H, S, S^{\prime}$ modes coexist, e.g., $\left[\mathrm{ML}\left\{\mathrm{H}_{2} \mathrm{~B}(\mathrm{mt})_{2}\right\}_{2}\right]\left(\mathrm{ML}=\mathrm{Ti}=\mathrm{N}^{t} \mathrm{Bu},{ }^{22 \mathrm{a}} \mathrm{WCO}^{22 \mathrm{~b}}\right)$. Indeed, even the $\mathrm{HB}(\mathrm{mt})_{3}, \mathrm{HB}(\mathrm{pz})(\mathrm{mt})_{2}, \mathrm{HB}\left(\mathrm{pz}^{\mathrm{MePh}}\right)\left(\mathrm{mt}^{\mathrm{tol}}\right)_{2}$, and

(19) (a) Malinakova, H. C.; Liebeskind, L. S. Org. Lett. 2000, 2, 39094083. (b) Yin, J.; Llorente, I.; Villanueva, L. A.; Liebeskind, L. S. J. Am. Chem. Soc. 2000, 122, 10458. (c) Shu, C.; Alcudia, A.; Yin, J.; Liebeskind, L. S. J. Am. Chem. Soc. 2001, 123, 12477. (d) Villanueva, L. A.; Ward, Y. D.; Lachicotte, R.; Liebeskind, L. S. Organometallics 1996, 15, 4190. (e) Ward, Y. D.; Villanueva, L. A.; Allred, G. D.; Liebeskind, L. S. Organometallics 1996, 15, 4201. (f) Ward, Y. D.; Villanueva, L. A.; Allred, G. D.; Liebeskind, L. S. J. Am. Chem. Soc. 1996, 118, 897. (g) Ward, Y. D.; Villanueva, L. A.; Allred, G. D.; Payne, S. C.; Semones, M. A.; Liebeskind, L. S. Organometallics 1995, 14, 4132. (h) Alcudia, A.; Arrayas, R. G.; Liebeskind, L. S. J. Org. Chem. 2002, 67, 5773. (i) Moretto, A. F.; Liebeskind, L. S. J. Org. Chem. 2000, 65, 7445. (j) Zhang, Y.; Liebeskind, L. S. J. Am. Chem. Soc. 2005, 127, 11258. (k) Zhang, Y.; Liebeskind, L. S. J. Am. Chem. Soc. 2006, 128, 465. (1) Yin, J.; Liebeskind, L. S. J. Am. Chem. Soc. 1999, 121, 5811.

(20) (a) Pearson, A. J.; Schoffers, E. Organometallics 1997, 16, 5365. (b) Pearson, A. J.; Douglas, A. R. Organometallics 1998, 17, 1446. (c) Pearson, A. J.; Neagu, I. B.; Pinkerton, A. A.; Kirschbaum, K.; Hardie, M. J. Organometallics 1997, 16, 4346. 411 .

(21) tom Dieck, H.; Friedel, H. J. Chem. Soc., Chem. Commun. 1969,

(22) (a) Hill, A. F.; Smith, M. K. Dalton Trans. 2006, 28. (b) Abernethy, R. J.; Hill, A. F.; Neumann, H.; Willis, A. C. Inorg. Chim. Acta 2005, 358, 1605 .

(23) (a) Garcia, R.; Domingos, A.; Paulo, A.; Santos, I.; Alberto, R. Inorg. Chem. 2002, 41, 2422. (b) Garcia, R.; Paulo, A.; Domingos, A.; Santos, I. Dalton Trans. 2003, 2757. (c) Garcia, R.; Paulo, A.; Domingos, A.; Santos, I.; Ortner, K.; Alberto, R. J. Am. Chem. Soc. 2000, 122, 11240. (d) Garcia, R.; Paulo, A.; Domingos, A.; Santos, I. J. Organomet. Chem. 2001, 632, 41. (e) Garcia, R.; Paulo, A.; Domingos, A.; Santos, I.; Pietzsch, H.-J. Synth. React. Inorg., Met.-Org., Nano-Met. Chem. 2005, 35, 35. 
$\mathrm{HB}(\operatorname{taz})_{3}$ (taz = 4-ethyl-1,4-dihydro-3-methyl-5-thioxo-1,2,4triazolyl) ligands have been shown to coordinate in this mode. ${ }^{24}$ As for the complexes $\mathbf{2}$ and $\mathbf{3}$ above, two synthetic approaches were employed to prepare $\mathrm{H}_{2} \mathrm{~B}(\mathrm{mt})_{2}$-ligated nitrosyl complexes that differ in the early or late introduction of the nitrosyl ligand.

Treating an acetonitrile solution of $\mathrm{Na}\left[\mathrm{Mo}(\mathrm{CO})_{3}\left\{\mathrm{H}_{2} \mathrm{~B}(\mathrm{mt})_{2}\right\}\right]^{9 \mathrm{a}}$ generated in situ from a mixture of $\left[\mathrm{Mo}(\mathrm{CO})_{6}\right]$ and $\mathrm{Na}\left[\mathrm{H}_{2} \mathrm{~B}(\mathrm{mt})_{2}\right]$ with Diazald resulted in an immediate reaction to provide the bright orange crystalline complex $\left[\mathrm{Mo}(\mathrm{NO})(\mathrm{CO})_{2}\left\{\mathrm{H}_{2} \mathrm{~B}(\mathrm{mt})_{2}\right\}\right]$ (5) in high yields (82\%). Although the reaction was carried out under mild conditions, no spectroscopic evidence (IR) was obtained for the presumed intermediate $\left[\mathrm{Mo}(\mathrm{NO})(\mathrm{CO})_{3}-\right.$ $\left.\left\{\mathrm{H}_{2} \mathrm{~B}(\mathrm{mt})_{2}\right\}\right]$, which must be short-lived. The infrared spectrum of $\mathbf{5}$ includes two carbonyl absorptions (Table S1, Supporting Information; 2028, $1945 \mathrm{~cm}^{-1}$ ) and one due to the nitrosyl ligand $\left(1661 \mathrm{~cm}^{-1}\right)$. Thus, it would appear that the $\mathrm{H}_{2} \mathrm{~B}(\mathrm{mt})_{2}$ ligand is a poorer net donor than is the $\mathrm{HB}(\mathrm{mt})_{3}$ ligand. Two coordination geometries may be considered on the basis of the $\mathrm{H}_{2} \mathrm{~B}(\mathrm{mt})_{2}$ ligand occupying one face of the octahedron: viz. $C_{s}$ (NO trans to $\mathrm{B}-\mathrm{H}-\mathrm{Mo}$ ) or $C_{1}$ (NO trans to $\mathrm{S}$ ). These are readily distinguished on the basis of ${ }^{1} \mathrm{H}$ and ${ }^{13} \mathrm{C}$ NMR data, which indicate that the latter is adopted by the appearance of resonances for two chemically distinct methimazoyl environments. Thus, two singlets $\left(\delta_{\mathrm{H}} 3.48,3.38\right)$ are observed for the $\mathrm{NCH}_{3}$ groups in the ${ }^{1} \mathrm{H}$ NMR spectrum, while the ${ }^{13} \mathrm{C}\left\{{ }^{1} \mathrm{H}\right\}$ NMR spectrum includes two resonances for the chemically inequivalent carbonyl ligands $\left(\delta_{\mathrm{C}} 216.7,224.3\right)$ and two resonances for the thione donors $\left(\delta_{\mathrm{C}} 159.6,163.2\right)$. The ${ }^{1} \mathrm{H}$ NMR spectrum also includes a peak for the $3 \mathrm{c}-2 \mathrm{e} \mathrm{B}-\mathrm{H}-\mathrm{Mo}$ interaction at characteristically high field, $\delta-3.80 \mathrm{ppm}$, showing quadrupolar broadening due to attachment of the hydrogen to boron. A similar resonance is observed at $\delta_{\mathrm{H}}-5.04 \mathrm{ppm}$ for the thiocarbamoyl complex $\left[\mathrm{Mo}\left(\eta^{2}-\mathrm{SCNMe}_{2}\right)(\mathrm{CO})_{2}\left\{\kappa^{3}-H, S, S^{\prime}-\right.\right.$ $\left.\left.\mathrm{H}_{2} \mathrm{~B}(\mathrm{mt})_{2}\right\}\right] .^{9 \mathrm{a}}$ The coordination of the $\mathrm{B}-\mathrm{H}$ group is also manifested in a lowering of the frequency of one of the $\mathrm{B}-\mathrm{H}$ infrared modes $\left(\mathrm{CH}_{2} \mathrm{Cl}_{2}: v_{\mathrm{BH}} 2435 \mathrm{~cm}^{-1}, v_{\mathrm{BHMo}} 2233 \mathrm{~cm}^{-1}\right)$. The formulation of $\mathbf{5}$ was further confirmed by elemental microanalysis and an X-ray crystallographic study (Figure 3, vide infra).

The tungsten analogue of 5, viz. [W(NO) $\left.(\mathrm{CO})_{2}\left\{\mathrm{H}_{2} \mathrm{~B}(\mathrm{mt})_{2}\right\}\right]$ (6), was initially prepared via an analogous procedure, with the distinction that preisolated $\left[\mathrm{W}(\mathrm{CO})_{3}(\mathrm{NCMe})_{3}\right]^{25}$ was employed. A solution of $\left[\mathrm{W}(\mathrm{CO})_{3}(\mathrm{NCMe})_{3}\right]$ in acetonitrile was first treated with $\mathrm{Na}\left[\mathrm{H}_{2} \mathrm{~B}(\mathrm{mt})_{2}\right]$ to provide, in situ, the salt $\mathrm{Na}\left[\mathrm{W}(\mathrm{CO})_{3}\right.$ $\left.\left\{\mathrm{H}_{2} \mathrm{~B}(\mathrm{mt})_{2}\right\}\right],{ }^{26}$ which was then subsequently treated with Diazald at room temperature to provide the orange complex $\left[\mathrm{W}(\mathrm{NO})(\mathrm{CO})_{2}\left\{\mathrm{H}_{2} \mathrm{~B}(\mathrm{mt})_{2}\right\}\right]$ in $64 \%$ yield. Data for 6 are comparable to those for $\mathbf{5}$, including both of the characteristic spectroscopic signatures for a three-center, two-electron $\mathrm{B}-\mathrm{H}-\mathrm{W}$ interaction (NMR $\delta_{\mathrm{H}}-3.16 \mathrm{ppm}$; IR $\nu_{\mathrm{BH}} 2417 \mathrm{~cm}^{-1}, \nu_{\mathrm{BHW}} 2228$ $\left.\mathrm{cm}^{-1}\right)$. The complex $\left[\mathrm{W}(\mathrm{CO})\left\{\mathrm{H}_{2} \mathrm{~B}(\mathrm{mt})_{2}\right\}_{2}\right]$ has similar spectroscopic features associated with this connectivity $\left(\mathrm{NMR} \delta_{\mathrm{H}}\right.$ $-3.58 \mathrm{ppm}$; IR $\left.v_{\mathrm{BH}} 2446, v_{\mathrm{BHW}} 2246 \mathrm{~cm}^{-1}\right){ }^{22 \mathrm{~b}}$

Given the isoelectronic relationship $\mathrm{WNO} \equiv \mathrm{ReCO}$, the complex 6 may be considered as an analogue of $\left[\operatorname{Re}(\mathrm{CO})_{3}\left\{\kappa^{3}-H, S, S^{\prime}-\right.\right.$

(24) (a) Foreman, M. R. St.-J.; Hill, A. F.; Owen, G. R.; White, A. J. P.; Williams, D. J. Organometallics 2003, 22, 4446. (b) Kimblin, C.; Bridgewater, B. M.; Churchill, D. G.; Hascall, T.; Parkin, G. Inorg. Chem. 2000, 39, 4240. (c) Shu, M.-H.; Tu, C.-L.; Cui, J.; Sun, J. Chin. J. Inorg. Chem. 2006, 22, 1507. (d) Blagg, R. J.; Charmant, J. P. H.; Connelly, N. G.; Haddow, M. F.; Orpen, A. G. Chem. Commun. 2006, 2350.

(25) Tate, D. P.; Knipple, W. R.; Aug, J. M. Inorg. Chem. 1962, 1, 433 .

(26) Although not isolated in this instance, the intermediate salt $\mathrm{Na}\left[\mathrm{W}(\mathrm{CO})_{3}\left\{\mathrm{H}_{2} \mathrm{~B}(\mathrm{mt})_{2}\right\}\right]$ has a rich chemistry which we will describe in a forthcoming paper.

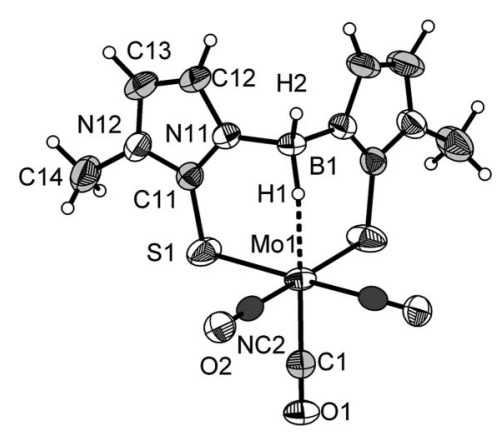

Figure 3. Molecular geometry of a crystal of $\mathbf{5} \cdot 0.5 \mathrm{EtOH}$ (heteroatoms in white, carbon atoms in light gray, pseudo atoms $\mathrm{NC} 2(=1 /$ ${ }_{2} \mathrm{~N}+{ }^{1} /{ }_{2} \mathrm{C}$ ) in dark gray, $50 \%$ displacement ellipsoids). One of the two crystallographically independent but similar molecules is shown. Selected bond lengths $(\AA)$ and angles (deg): Mo1-S1 = $2.5225(12), \mathrm{Mo} 1-\mathrm{NC} 2=1.900(4), \mathrm{Mo} 1-\mathrm{C} 1=2.010(6), \mathrm{Mo} 1-\mathrm{H} 1$ $=1.95(6), \mathrm{S} 1-\mathrm{C} 11=1.702(4), \mathrm{O} 1-\mathrm{C} 1=1.134(6), \mathrm{O} 2-\mathrm{CN} 2=$ $1.175(4), \mathrm{N} 11-\mathrm{C} 11=1.351(5), \mathrm{N} 11-\mathrm{C} 12=1.395(5), \mathrm{N} 11-\mathrm{B} 1$ $=1.538(4), \mathrm{N} 12-\mathrm{C} 11=1.348(5), \mathrm{N} 12-\mathrm{C} 13=1.385(6), \mathrm{N} 12-\mathrm{C} 14$ $=1.451(6), \mathrm{B} 1-\mathrm{H} 1=1.14(5), \mathrm{B} 1-\mathrm{H} 2=1.16(5) ; \mathrm{S} 1-\mathrm{Mo} 1-\mathrm{CN} 2$ $=89.64(10), \mathrm{S} 1-\mathrm{Mo} 1-\mathrm{S} 1 *=90.10(7), \mathrm{CN} 2-\mathrm{Mo} 1-\mathrm{S} 1 *=$ 179.14(10), CN2-Mo1-CN2* = 90.6(2), S1-Mo1-H1 = 86.5(11), $\mathrm{CN} 2-\mathrm{Mo} 1-\mathrm{H} 1=92.7(11), \mathrm{C} 1-\mathrm{Mo} 1-\mathrm{H} 1=175.7(16), \mathrm{Mo} 1-\mathrm{S} 1-\mathrm{C} 11$ $=105.07(14), \mathrm{H} 1-\mathrm{B} 1-\mathrm{H} 2=106(4), \mathrm{Mo} 1-\mathrm{H} 1-\mathrm{B} 1=142(4)$ (asterisk indicates symmetry-generated counterpart). See Figure S2 (Supporting Information) for an alternative view.

$\left.\mathrm{H}_{2} \mathrm{~B}(\mathrm{mt})_{2}\right\}$ ] (7) described previously by Santos. ${ }^{23}$ A remarkable feature of $\mathbf{7}$ is the facile opening of the $\kappa^{3}-\mathrm{H}, \mathrm{S}, \mathrm{S}^{\prime}$ coordination mode upon addition of a range of ligands to provide $\left[\operatorname{Re}(\mathrm{CO})_{3}(\mathrm{~L})\left\{\kappa^{2}-\right.\right.$ $\left.S, S^{\prime}-\mathrm{H}_{2} \mathrm{~B}(\mathrm{mt})_{2}\right\}$ ] ( $\mathrm{L}=$ imidazole, 4-(dimethylamino)pyridine, $\mathrm{CN}^{t} \mathrm{Bu}, \mathrm{PPh}_{3}$ ) at room temperature. Surprisingly, such behavior is not observed for $\mathbf{6}$, such that no reaction occurs between $\mathbf{6}$ and $\mathrm{PPh}_{3}$ under ambient conditions. The anticipated complex $\left[\mathrm{W}(\mathrm{NO})(\mathrm{CO})_{2}\left(\mathrm{PPh}_{3}\right)\left\{\mathrm{H}_{2} \mathrm{~B}(\mathrm{mt})_{2}\right\}\right](8)$ may, however, be prepared via an alternative synthetic route. Treating a solution of $\left[\mathrm{W}(\mathrm{NO})(\mathrm{CO})_{3}\left(\mathrm{PPh}_{3}\right)_{2}\right] \mathrm{PF}_{6}\left(\mathbf{1}-\mathbf{P F}_{6}\right)$ with $\mathrm{Na}\left[\mathrm{H}_{2} \mathrm{~B}(\mathrm{mt})_{2}\right]$ at room temperature slowly affords the orange complex $\mathbf{8}$ in $70 \%$ yield. Spectroscopic data for $\mathbf{8}$ indicate that the molecule does not possess an element of symmetry. Thus, two methimazolyl environments are apparent in the ${ }^{1} \mathrm{H}$ and ${ }^{13} \mathrm{C}\left\{{ }^{1} \mathrm{H}\right\}$ NMR spectra, the latter including two resonances for the chemically distinct carbonyl ligands; notably, only one of these shows resolvable coupling to phosphorus. The infrared and ${ }^{1} \mathrm{H}$ NMR spectra are devoid of the characteristic signatures for a three-center, twoelectron $\mathrm{B}-\mathrm{H}-\mathrm{W}$ interaction. The (chiral) molecular geometry that follows from solution spectroscopic data (Scheme 2) is also adopted in the solid state (Figure 4, vide infra), though the refinement of nitrosyl and carbonyl sites was guided by these data. Early indications in the model refinement suggested that the two diatomics trans to the sulfur donors were a disordered $\mathrm{NO} / \mathrm{CO}$ pair, as observed for $\mathbf{5}$. However, in contrast to $\mathbf{5}$, the entire molecule of $\mathbf{8}$ is crystallographically unique and does not straddle crystallographic symmetry elements. Thus, a 50:50 site disorder is not crystallographically requisite and accordingly the occupancies of the donor atoms were refined (ca. 32:68).

Given that $\left[\mathrm{W}(\mathrm{NO})(\mathrm{CO})_{2}\left\{\mathrm{H}_{2} \mathrm{~B}(\mathrm{mt})_{2}\right\}\right]$ (6) fails to react with triphenylphosphine, we expected that the phosphine ligand in $\left[\mathrm{W}(\mathrm{NO})(\mathrm{CO})_{2}\left(\mathrm{PPh}_{3}\right)\left\{\mathrm{H}_{2} \mathrm{~B}(\mathrm{mt})_{2}\right\}\right](8)$ would be labile and eventually provide 6. Although not exhaustively tested, heating $\mathbf{8}$ in thf under reflux for $12 \mathrm{~h}$ provided essentially quantitative recovery of $\mathbf{8}$ with no formation of $\mathbf{6}$ within spectroscopically determinable limits (solution IR). This behavior is in contrast with the formation of $\mathbf{2}$, where no intermediate of the form $\left[\mathrm{W}(\mathrm{NO})(\mathrm{CO})_{2}\left(\mathrm{PPh}_{3}\right)\left\{\kappa^{2}-\mathrm{HB}(\mathrm{mt})_{3}\right\}\right]$ was observed. 
Scheme 2. Synthesis of Dihydrobis(methimazolyl)borato Nitrosyl Complexes ${ }^{a}$
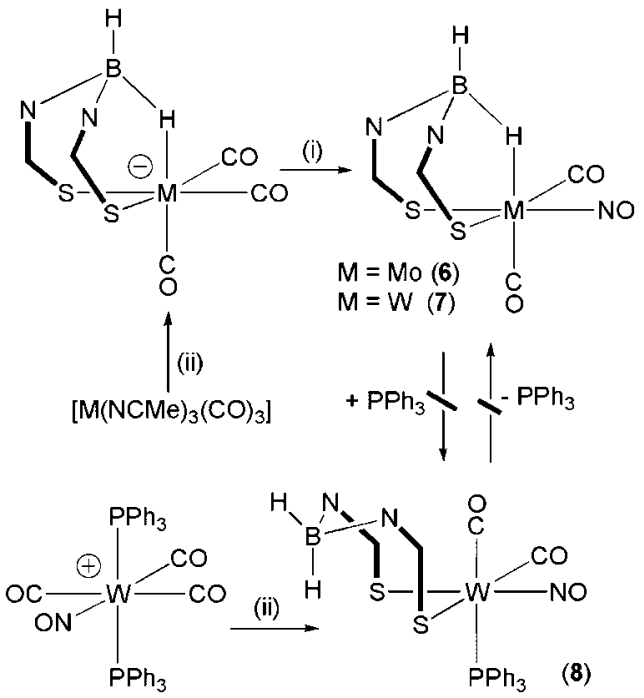

${ }^{a}$ Legend: (i) $\mathrm{ONNMeSO}_{2} \mathrm{C}_{6} \mathrm{H}_{4} \mathrm{Me}-4$; (ii) $\mathrm{Na}\left[\mathrm{H}_{2} \mathrm{~B}(\mathrm{mt})_{2}\right]$.

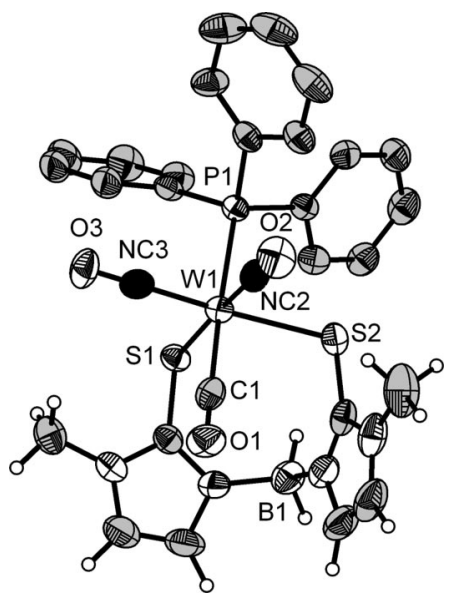

Figure 4. Molecular geometry of a crystal of $\mathbf{8} \cdot \mathrm{CH}_{2} \mathrm{Cl}_{2}$ (heteroatoms in white, carbon atoms in light gray, pseudo atoms $\mathrm{NC} 2$ $(=0.68 \mathrm{~N}+0.32 \mathrm{C})$ and $\mathrm{NC} 3(=0.32 \mathrm{~N}+0.68 \mathrm{C})$ in dark gray, $50 \%$ displacement ellipsoids, phenyl hydrogen atoms and $\mathrm{CH}_{2} \mathrm{Cl}_{2}$ solvate omitted). Selected bond lengths $(\AA)$ and angles (deg): $\mathrm{W} 1-\mathrm{S} 1=$ $2.5569(13), \mathrm{W} 1-\mathrm{S} 2=2.5635(14), \mathrm{W} 1-\mathrm{P} 1=2.5647(13), \mathrm{W} 1-\mathrm{NC} 3$ $=1.864(5), \mathrm{W} 1-\mathrm{C} 1=2.014(6), \mathrm{W} 1-\mathrm{NC} 2=1.905(5), \mathrm{S} 1-\mathrm{C} 11$ $=1.733(5), \mathrm{S} 2-\mathrm{C} 21=1.729(6), \mathrm{O} 1-\mathrm{C} 1=1.148(7), \mathrm{N} 11-\mathrm{B} 1$ $=1.568(9), \mathrm{N} 21-\mathrm{B} 1=1.565(9), \mathrm{B} 1-\mathrm{H} 11=1.050 ; \mathrm{S} 1-\mathrm{W} 1-\mathrm{S} 2$ $=91.34(4), \mathrm{S} 1-\mathrm{W} 1-\mathrm{P} 1=84.34(4), \mathrm{S} 2-\mathrm{W} 1-\mathrm{P} 1=86.23(4)$, $\mathrm{S} 1-\mathrm{W} 1-\mathrm{C} 1=91.70(16), \mathrm{S} 2-\mathrm{W} 1-\mathrm{C} 1=89.85(15), \mathrm{P} 1-\mathrm{W} 1-\mathrm{C} 1$ $=174.36(15), \mathrm{W} 1-\mathrm{S} 1-\mathrm{C} 11=103.61(17), \mathrm{W} 1-\mathrm{S} 2-\mathrm{C} 21=$ 104.08(18), N11-B1-N21 = 109.2(5).

Crystal Structures of $\left[\mathrm{W}(\mathrm{NO})(\mathrm{CO})_{2}\left\{\mathrm{HB}(\mathrm{mt})_{3}\right\}\right](2)$, [Mo$\left.(\mathrm{NO})(\mathrm{CO})_{2}\left\{\mathrm{H}_{2} \mathrm{~B}(\mathrm{mt})_{2}\right\}\right]$ (5) and $\left[\mathrm{W}(\mathrm{NO})(\mathrm{CO})_{2}\left(\mathrm{PPh}_{3}\right)\left\{\mathrm{H}_{2} \mathrm{~B}\right.\right.$ $\left.\left.(\mathbf{m t})_{2}\right\}\right](\mathbf{8})$. Before commencing a discussion of the structural features of $\mathbf{2}, \mathbf{5}$, and $\mathbf{8}$, it is worthwhile to consider the isoelectronic relationship between "WN" and "ReC": i.e., the complexes $\left[\operatorname{Re}(\mathrm{CO})_{3}\left\{\mathrm{HB}(\mathrm{mt})_{3}\right\}\right](\mathbf{9}),\left[\operatorname{Re}(\mathrm{CO})_{3}\left\{\mathrm{H}_{2} \mathrm{~B}(\mathrm{mt})_{2}\right\}\right](\mathbf{7})$, and $\left[\operatorname{Re}(\mathrm{CO})_{3}\left(\mathrm{PPh}_{3}\right)\left\{\mathrm{H}_{2} \mathrm{~B}(\mathrm{mt})_{2}\right\}\right](\mathbf{1 0})$, each reported by Santos, may be considered isosteric and isoelectronic analogues of $\mathbf{2 , 6}$, and $\mathbf{8}$, respectively. Similarly, the technetium and manganese complexes $\left[\mathrm{M}(\mathrm{CO})_{3}\left\{\mathrm{HB}(\mathrm{mt})_{3}\right\}\right]$ and $\left[\mathrm{M}(\mathrm{CO})_{3}\left\{\mathrm{H}_{2} \mathrm{~B}(\mathrm{mt})_{2}\right\}\right](\mathrm{M}=$ $\mathrm{Tc}, \mathrm{Mn})$ have been described. ${ }^{9 \mathrm{i}, \mathrm{p}, 26}$ The complexes $\left[\mathrm{M}(\mathrm{CO})_{3^{-}}\right.$ $\left.\left\{\mathrm{HB}(\mathrm{mt})_{3}\right\}\right](\mathrm{M}=\mathrm{Mn}, \mathrm{Re})$ each crystallize in the trigonal space group $R 3$ and, despite the disparity in nitrosyl and carbonyl
Chart 2. Parameters Describing $\mathrm{HB}(\mathrm{mt})_{3} \mathrm{M}$ Cages $^{a}$

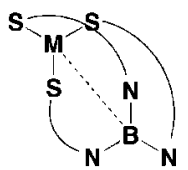

$\stackrel{\lambda}{\left(\theta<0^{\circ}\right)}$

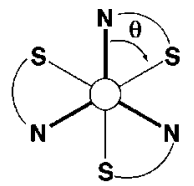

$\delta$

$\left(\theta>0^{\circ}\right)$

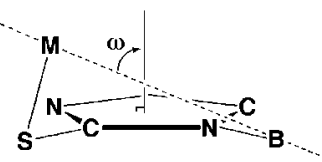

${ }^{a} \theta^{\mathrm{m}}$ and $\omega^{\mathrm{m}}$ refer to the mean values for three $\mathrm{B}(\mathrm{mt}) \mathrm{M}$ groups.

ligands, $\mathbf{2}$ does as well, with similar unit cell parameters. The $\mathrm{B}-\mathrm{W}$ vectors of the two crystallographically independent molecules are collinear with the crystallographic 3-fold axis. Accordingly, satisfactory refinement was based on pseudo atoms "NC" comprising $1 / 3 \mathrm{~N}+{ }^{2} / 3 \mathrm{C}$, with identical positional and displacement parameters. Metal-nitrosyl and metal-carbonyl bond lengths generally differ, such that this constraint is manifested in the thermal ellipsoids being elongated along the $\mathrm{W}-\mathrm{NC}$ vector. Accordingly, a detailed discussion of the geometry of the $\mathrm{W}(\mathrm{NO})(\mathrm{CO})_{2}$ fragment is not appropriate. The chirality that is intrinsic in $\mathrm{HB}(\mathrm{mt})_{3} \mathrm{M}$ cages is notable in the structure of $\mathbf{2}$ in that both independent molecules adopt the $\lambda$ arrangement: ${ }^{6}$ i.e., the single crystal is a single enantiomer. We have previously suggested that the parameter $\theta^{\mathrm{m}}$ (the mean $\mathrm{N}-\mathrm{B}-\mathrm{M}-\mathrm{S}$ torsional angle, Chart 2) might be a useful singular variable to describe the twisting of $\mathrm{HB}(\mathrm{mt})_{3} \mathrm{M}$ cages about the $\mathrm{B} \cdots \mathrm{M}$ axis $\left(\theta^{\mathrm{m}}=0\right.$ corresponds to the implausible $C_{3 v}$ $\mathrm{HB}(\mathrm{mt})_{3} \mathrm{M}$ geometry). For $\mathbf{2}$ this proves to be the case, highlighting the key difference between the two crystallographically independent molecules. One molecule (based on "W1") has $\theta^{\mathrm{m}}=47.30^{\circ}$, while the second molecule (based on "W2") has $\theta^{\mathrm{m}}=41.33^{\circ}$. There is a modest contraction of the mean $\mathrm{W}-\mathrm{S}$ bond length from 2.567 to $2.548 \AA$ that accompanies the greater twisting of the $\mathrm{B}(\mathrm{mt})_{3} \mathrm{~W}$ cage of the molecule based on W1, though the tungsten-boron separation remains essentially unchanged $(\mathrm{W} 1 \cdots \mathrm{B} 1=4.236 \AA$; cf. $\mathrm{W} 2 \cdots \mathrm{B} 2=4.245 \AA$ ). Intriguingly, the isomorphous compounds $\left[\operatorname{Re}(\mathrm{CO})_{3}\{\mathrm{HB}-\right.$ $\left.\left.(\mathrm{mt})_{3}\right\}\right]^{23 \mathrm{a}}\left(\theta^{\mathrm{m}}=47.2,42.8^{\circ}\right)$ and $\left[\mathrm{Mn}(\mathrm{CO})_{3}\left\{\mathrm{HB}(\mathrm{mt})_{3}\right\}\right]^{9 \mathrm{i}}\left(\theta^{\mathrm{m}}\right.$ $=41.4,46.9^{\circ}$ ) also display this pattern of one molecule being slightly more twisted than the second. These data, taken together, provide an indication of the degree of flexibility of the $\mathrm{B}(\mathrm{mt})_{3} \mathrm{M}$ cage in response to crystal-packing forces. The complex $\left[\operatorname{Re}(\mathrm{CO})_{3^{-}}\right.$ $\left.\left\{\mathrm{MeB}(\mathrm{mt})_{3}\right\}\right],{ }^{23 \mathrm{~b}}$ however, does not show any substantial variation between the two crystallographically unique molecules $\left(\theta^{\mathrm{m}}=48.03,49.50^{\circ}\right)$.

As with $\mathbf{2}$, the crystal of $\mathbf{5}$ is of higher symmetry (Pnnm) than the molecular geometry $\left(C_{1}\right)$. Thus, although the molecule is chiral, it straddles a crystallographic mirror plane, by virtue of the disorder of the isosteric nitrosyl and carbonyl ligands. These ligands have been once again modeled with the pseudoatom "NC" comprising $1 / 2 \mathrm{~N}+1 / 2 \mathrm{C}$. Notwithstanding the compromised precision of the $\mathrm{Mo}(\mathrm{NO})(\mathrm{CO})$ fragment, the structural feature of interest is the $\mathrm{B}-\mathrm{H}-\mathrm{Mo}$ interaction. Bearing in mind the caveats associated with the location of hydrogen atom sites close to heavy metals, the $\mathrm{Mo}-\mathrm{H}$ bond length of $1.95(6) \AA$ is comparable to that found in $\left[\mathrm{Mo}\left(\eta^{2}-\right.\right.$ $\left.\left.\mathrm{SCMe}_{2}\right)(\mathrm{CO})_{2}\left\{\mathrm{H}_{2} \mathrm{~B}(\mathrm{mt})_{2}\right\}\right](1.92(4) \AA)$ and subtends a $\mathrm{Mo}-\mathrm{H}-\mathrm{B}$ angle of $142(4)^{\circ}$. A more precise indication of the $3 c-2 e$ $\mathrm{B}-\mathrm{H}-$ Mo interaction is given by the Mo $\cdots \mathrm{B}$ length of 2.918 
Chart 3. Geometric Implications of Ring Size on the Angle of B-H Approach to a Metal<smiles>[M]CN(C)N(B)C</smiles><smiles>[M]C1SNBCC1C</smiles>

$\AA$, which again is comparable to the Mo $\cdots \mathrm{B}$ separations observed in the complexes $\left[\mathrm{Mo}\left(\eta^{2}-\mathrm{SCNMe}_{2}\right)(\mathrm{CO})_{2}\left\{\kappa^{3}-H, S, S^{\prime}-\right.\right.$ $\left.\left.\mathrm{H}_{2} \mathrm{~B}(\mathrm{mt})_{2}\right\}\right](2.964 \AA)^{9 \mathrm{a}}$ and $\left[\mathrm{Mo}\left(\mathrm{SnClMe}_{2}\right)(\mathrm{CO})_{3}\left\{\mathrm{H}_{2} \mathrm{~B}(\mathrm{mt})_{2}\right\}\right]$ $(2.982 \AA) .{ }^{27}$ Structural data for chelated $\mathrm{B}-\mathrm{H}-$ Mo interactions are somewhat sparse but do include the classic bis(pyrazolyl)borate complexes first reported by Trofimenko. Thus, the complexes $\left[\mathrm{Mo}\left(\eta^{3}-\mathrm{C}_{3} \mathrm{H}_{4} \mathrm{Me}\right)(\mathrm{CO})_{2}\left\{\kappa^{3}-H, N, N^{\prime}-\mathrm{HB}(\mathrm{pzMe})_{2}\right\}\right]$, $\left[\mathrm{Mo}\left(\eta^{3}-\right.\right.$ $\left.\left.\mathrm{C}_{3} \mathrm{H}_{4} \mathrm{Me}\right)(\mathrm{CO})_{2}\left\{\kappa^{3}-H, N, N^{\prime}-\mathrm{H}_{2} \mathrm{~B}\left(\mathrm{pzBr}_{3}\right)_{2}\right\}\right]$, and $\left[\mathrm{Mo}\left(\eta^{3}-\mathrm{C}_{3} \mathrm{H}_{5}\right)-\right.$ $\left.(\mathrm{CO})_{2}\left\{\kappa^{3}-H, N, N^{\prime}-\mathrm{H}_{2} \mathrm{~B}\left(\mathrm{pzMe}_{2}\right)_{2}\right\}\right]$ have Mo $\cdots$ B separations of $2.818,2.858$, and $2.817 \AA$, respectively: ${ }^{28}$ i.e., considerably shorter than observed for the $\mathrm{H}_{2} \mathrm{~B}(\mathrm{mt})_{2}$ complexes discussed. However, this does not necessarily reflect a weaker $\mathrm{B}-\mathrm{H}-\mathrm{Mo}$ interaction on the part of $\mathrm{H}_{2} \mathrm{~B}(\mathrm{mt})_{2}$ coordination but, rather, a corollary of the geometric requirements of including an extra atom in the "metallacycle" (Chart 3).

The complex $\mathbf{8}$ has no molecular element of symmetry. However, once again, as for $\mathbf{5}$, disorder of the nitrosyl and one carbonyl ligand occurs. In contrast to the case for $\mathbf{5}$, the $\kappa^{2}-S, S^{\prime}$ coordination mode is adopted by the $\mathrm{H}_{2} \mathrm{~B}(\mathrm{mt})_{2}$ ligand such that the $\mathrm{BH}_{2}$ is distal to the metal center while the metallacycle adopts a sigmoidal chair arrangement (Chart 1a), allowing the two methimazolyl heterocycles to lie either side of the carbonyl ligand. In this coordination mode, the $\mathrm{S} 1-\mathrm{W} 1-\mathrm{S} 2$ angle of $91.34(4)^{\circ}$ in $\mathbf{8}$ is comparable to the $\mathrm{S} 1-\mathrm{Mo} 1-\mathrm{S} 1 *$ angle of $90.10(7)^{\circ}$ found in 5: i.e., chelate bite size is not a determinant in the preference for coordination mode.

\section{Conclusions}

Synthetic routes to a range of poly(methimazolyl)borato nitrosyl complexes have been developed. These proceed in respectable yields, making these compounds now available for further study. A notable feature to emerge is the prevalence of the $\kappa^{3}-\mathrm{H}, \mathrm{S}, \mathrm{S}^{\prime}$ bonding mode for the $\mathrm{H}_{2} \mathrm{~B}(\mathrm{mt})_{2}$ ligand, even in the presence of extraneous ligands, which in the case of isoelectronic rhenium complexes effect opening of the $\mathrm{B}-\mathrm{H}-\mathrm{Re}$ interaction. The lability of the $\mathrm{B}-\mathrm{H}-\mathrm{Re}$ interaction in $\left[\operatorname{Re}(\mathrm{CO})_{3}\left\{\mathrm{H}_{2} \mathrm{~B}(\mathrm{mt})_{2}\right\}\right]$ and inert nature of the isoelectronic complex $\left[\mathrm{W}(\mathrm{NO})(\mathrm{CO})_{2}\left\{\mathrm{H}_{2} \mathrm{~B}(\mathrm{mt})_{2}\right\}\right]$ is intriguing. If anything, the presence of a nitrosyl ligand might have been expected to further activate the complex toward associative ligand substitution, recalling Basolo's classical demonstration, ${ }^{29}$ wherein $\left[\mathrm{Mn}(\mathrm{NO})(\mathrm{CO})_{4}\right]$ and $\left[\mathrm{Fe}(\mathrm{CO})_{5}\right]$ were found to react with $\mathrm{PPh}_{3}$ via $S_{N} 2$ and $S_{N} 1$ processes, respectively. Nevertheless, an example of this ligand bound to tungsten in the $\kappa^{2}-\mathrm{S}, \mathrm{S}^{\prime}$ coordination mode could be accessed via an alternative route, structurally characterized, and shown to not expel phosphine.

(27) Foreman, M. R. St.-J.; Hill, A. F.; Smith, M. K.; Tshabang, N. Organometallics 2005, 24, 5224.

(28) (a) Rheingold, A. L.; Liable-Sands, L. M.; Incarvito, C. L.; Trofimenko, S. Dalton Trans. 2002, 2297. (b) Chowdhury, S. K.; Samanta, U.; Puranik, V. G.; Sarkar, A. Organometallics 1997, 16, 2618. (c) Kosky, C. A.; Ganis, P.; Avitabile, G. Acta Crystallogr., Sect. B: Struct. Crystallogr. Cryst. Chem. 1971, 27, 1859.

(29) Wawersik, H.; Basolo, F. J. Am. Chem. Soc. 1967, 89, 4626.
Scheme 3. Synthesis of $\left[\mathrm{Mo}\left(\eta^{3}-\mathrm{C}_{3} \mathrm{H}_{5}\right)(\mathrm{CO})_{2}\left\{\mathrm{HB}(\mathrm{mt})_{3}\right\}\right]^{a}$

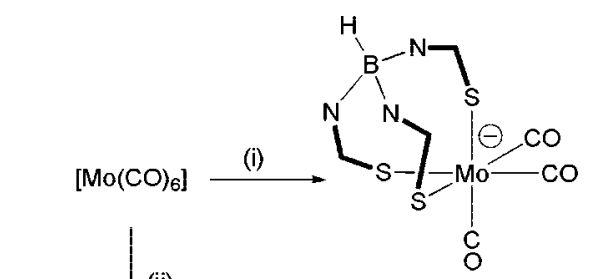

(ii)

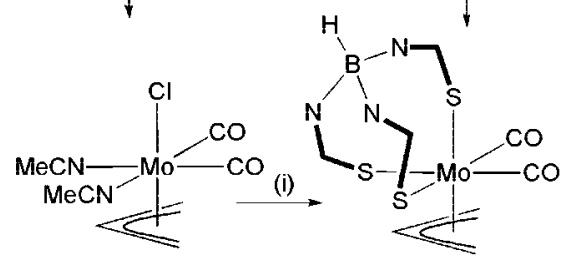

${ }^{a}$ Legend: (i) $\mathrm{Na}\left[\mathrm{HB}(\mathrm{mt})_{3}\right]$; $\mathrm{BrCH}_{2} \mathrm{CH}=\mathrm{CH}_{2} .{ }^{16}$

\section{Experimental Section}

General Considerations. All manipulations were carried out under a dry and oxygen-free nitrogen atmosphere using standard Schlenk, vacuum line, and inert-atmosphere drybox techniques, with dried and degassed solvents which were distilled from either calcium hydride $\left(\mathrm{CH}_{2} \mathrm{Cl}_{2}, \mathrm{MeCN}\right)$ or sodium-potassium alloy and benzophenone (ethers and paraffins). NMR spectra were obtained at $25^{\circ} \mathrm{C}$ on a Varian Gemini 300BB spectrometer $\left({ }^{1} \mathrm{H}\right.$ at 299.945 $\mathrm{MHz}$ and ${ }^{13} \mathrm{C}$ at $75.428 \mathrm{MHz}$, referenced to external $\mathrm{SiMe}_{4} ;{ }^{31} \mathrm{P}$ at 121.420 MHz, referenced to external $85 \% \mathrm{H}_{3} \mathrm{PO}_{4} ;{ }^{11} \mathrm{~B}$ at 96.232 $\mathrm{MHz}$, referenced to external $\left.\mathrm{BF}_{3} \cdot \mathrm{OEt}_{2}\right)$. ${ }^{11} \mathrm{~B} \mathrm{NMR}$ spectra were on occasion measured in $d_{6}$-dmso to maximize solubility when using conventional borosilicate (rather than low-boron) NMR tubes. This solvent is less ideal for ${ }^{1} \mathrm{H}$ and ${ }^{13} \mathrm{C}$ NMR measurements when there is the possibility of $\mathrm{S}^{13} \mathrm{CHD}_{2}$ peaks obscuring the $\mathrm{N}-\mathrm{CH}_{3}$ resonances of interest. Elemental microanalysis was performed by the microanalytical service of the Australian National University. Electrospray (ESI), FAB, and electron impact (EI) mass spectrometry was performed by the Research School of Chemistry mass spectrometry service. Data for X-ray crystallography were collected with a Nonius Kappa CCD diffractometer. The compounds $\mathrm{Na}[\mathrm{H}-$ $\left.\mathrm{B}(\mathrm{mt})_{3}\right],{ }^{13} \mathrm{Na}\left[\mathrm{H}_{2} \mathrm{~B}(\mathrm{mt})_{2}\right],{ }^{9 \mathrm{a}}\left[\mathrm{W}(\mathrm{NO})(\mathrm{CO})_{3}\left(\mathrm{PPh}_{3}\right)_{2}\right] \mathrm{PF}_{6}\left(\mathbf{1}-\mathbf{P F}_{\mathbf{6}}\right),{ }^{12}$ $\left[\mathrm{MoCl}\left(\eta^{3}-\mathrm{C}_{3} \mathrm{H}_{5}\right)(\mathrm{NCMe})_{2}(\mathrm{CO})_{2}\right],{ }^{30}$ and $\left[\mathrm{W}(\mathrm{CO})_{3}(\mathrm{NCMe})_{3}\right]^{25}$ were prepared according to the indicated published procedures. The complex $\left[\mathrm{Mo}(\mathrm{CO})_{2}\left(\eta^{3}-\mathrm{C}_{3} \mathrm{H}_{5}\right)\left\{\mathrm{HB}(\mathrm{mt})_{3}\right\}\right]$ (4) has been previously prepared via the reaction of $\mathrm{Na}\left[\mathrm{Mo}(\mathrm{CO})_{3}\left\{\mathrm{HB}(\mathrm{mt})_{3}\right\}\right]$ with allyl bromide (40\% yield). ${ }^{16}$ For the present work, the complex 4 was prepared via the reaction of $\left[\mathrm{MoCl}\left(\eta^{3}-\mathrm{C}_{3} \mathrm{H}_{5}\right)(\mathrm{NCMe})_{2}(\mathrm{CO})_{2}\right]^{30}$ with $\mathrm{Na}\left[\mathrm{HB}(\mathrm{mt})_{3}\right]$ (Scheme 3; 75\% yield), details of which are provided below. Other reagents were used as received from commercial suppliers.

Synthesis of $\left[\mathrm{W}(\mathrm{NO})(\mathrm{CO})_{2}\left\{\mathrm{HB}(\mathrm{mt})_{3}\right\}\right]$ (2). Method a. A mixture of the salt trans, mer $\left[\mathrm{W}(\mathrm{CO})_{3}(\mathrm{NO})\left(\mathrm{PPh}_{3}\right)_{2}\right]\left[\mathrm{PF}_{6}\right]^{12}\left(\mathbf{1}-\mathbf{P F}_{\mathbf{6}}\right.$; $0.52 \mathrm{~g}, 0.52 \mathrm{mmol})$ and $\mathrm{Na}\left[\mathrm{HB}(\mathrm{mt})_{3}\right]^{13}(0.19 \mathrm{~g}, 0.52 \mathrm{mmol})$ were heated in $\mathrm{CH}_{2} \mathrm{Cl}_{2}(60 \mathrm{~mL})$ under reflux for $24 \mathrm{~h}$. A color change from bright yellow to orange was observed. The orange solution was filtered through diatomaceous earth and the solvent volume of the filtrate reduced by half (ca. $30 \mathrm{~mL}$ ) and then diluted with ethanol $(30 \mathrm{~mL})$. The solvent volume was further reduced slowly (rotary evaporator) to provide a bright orange microcrystalline product. The product was filtered off, washed with ethanol $(2 \times 20 \mathrm{~mL})$, and dried in vacuo. Yield: $0.24 \mathrm{~g}(75 \%)$.

Method b. A mixture of [W(CO) 6 (6.10 g, $17.3 \mathrm{mmol})$ and $\mathrm{Na}\left[\mathrm{HB}(\mathrm{mt})_{3}\right]^{13}(7.66 \mathrm{~g}, 22.6 \mathrm{mmol})$ in dry degassed acetonitrile

(30) tom Dieck, H.; Friedel, H. J. Organomet. Chem. 1968, 14, 375. 
$(80 \mathrm{~mL})$ was heated under reflux for $18 \mathrm{~h}$ and then cooled to room temperature. $N$-Methyl- $N$-nitroso-4-toluenesulfonamide (Diazald, $4.05 \mathrm{~g}, 18.9 \mathrm{mmol}$ ) was slowly added to the cooled solution, resulting in the formation of an orange precipitate. The mixture was stirred for a further $15 \mathrm{~h}$, after which time the precipitate was isolated by filtration, recrystallized from a mixture of dichloromethane and ethanol, washed with diethyl ether, and dried in vacuo. Yield: $3.31 \mathrm{~g}$ (31\%). IR (Nujol): $2497 v(\mathrm{BH}), 1977,1872$ $v(\mathrm{CO}), 1613 v(\mathrm{NO}) \mathrm{cm}^{-1}$. IR $\left(\mathrm{CH}_{2} \mathrm{Cl}_{2}\right): 2410 v(\mathrm{BH}), 1992,1893$ $v(\mathrm{CO}), 1616 v(\mathrm{NO}) \mathrm{cm}^{-1}$. A comparison of absorbances for the $v_{\mathrm{s}}(\mathrm{CO})$ and $v_{\text {as }}(\mathrm{CO})$ modes $\left(\mathrm{CH}_{2} \mathrm{Cl}_{2}\right)$ indicates an intercarbonyl angle of $95^{\circ}$ in solution (cf. $90.4^{\circ}$ in the solid state, vide infra). ${ }^{1} \mathrm{H}$ NMR $\left(25^{\circ} \mathrm{C}, \mathrm{CD}_{2} \mathrm{Cl}_{2}\right): \delta_{\mathrm{H}} 3.66\left(\mathrm{~s}, 3 \mathrm{H}, \mathrm{NCH}_{3}\right), 3.70(\mathrm{~s}, 6 \mathrm{H}$, $\left.\mathrm{NCH}_{3}\right), 6.84,6.88\left(\mathrm{~d} \times 2,{ }^{3} J_{\mathrm{HH}}=1.9 \mathrm{~Hz}, 1 \mathrm{H} \times 2, \mathrm{NHC}=\mathrm{CHN}\right)$, $6.90,6.92\left(\mathrm{~d},{ }^{3} J_{\mathrm{HH}}=2.1 \mathrm{~Hz}, 2 \mathrm{H} \times 2, \mathrm{NHC}=\mathrm{CHN}\right) \mathrm{ppm} .{ }^{1} \mathrm{H}$ $\operatorname{NMR}\left(25^{\circ} \mathrm{C}, \mathrm{CDCl}_{3}\right): \delta_{\mathrm{H}} 3.54\left(\mathrm{~s}, 3 \mathrm{H}, \mathrm{NCH}_{3}\right), 3.65\left(\mathrm{~s}, 3 \mathrm{H}, \mathrm{NCH}_{3}\right)$, $3.67\left(\mathrm{~s}, 3 \mathrm{H}, \mathrm{NCH}_{3}\right), 6.73,6.80\left(\mathrm{~d},{ }^{3} J_{\mathrm{HH}}=2.1 \mathrm{~Hz}, 2 \mathrm{H}\right.$, $\mathrm{NHC}=\mathrm{CHN}), 6.80,6.82\left(\mathrm{~d},{ }^{3} J_{\mathrm{HH}}=2.1 \mathrm{~Hz}, 4 \mathrm{H}, \mathrm{NHC}=\mathrm{CHN}\right)$ ppm. ${ }^{11} \mathrm{~B}\left\{{ }^{1} \mathrm{H}\right\}$ NMR $\left(d_{6}\right.$-DMSO): $\delta_{\mathrm{B}} 3.22 \mathrm{ppm}$. APCI-MS; $m / z(\%)$ $565.1(55)\left[\mathrm{M}-\mathrm{CO}-\mathrm{NO}^{+}, 533.1(10)\left[\mathrm{M}-2 \mathrm{CO}-\mathrm{NO}^{+}\right.\right.$. ESI-MS; $m / z(\%) 643(30)[\mathrm{M}+\mathrm{Na}]^{+}, 615(45)[\mathrm{M}+\mathrm{Na}-\mathrm{CO}]^{+}$, $587(100)[\mathrm{M}+\mathrm{Na}-2 \mathrm{CO}]^{+}$. Anal. Found: C, 26.85; H, 2.66; N, 15.49. Calcd for $\mathrm{C}_{14} \mathrm{H}_{16} \mathrm{BN}_{7} \mathrm{O}_{3} \mathrm{~S}_{3} \mathrm{~W}$ : C, 27.07; H, 2.60; N, $15.78 \%$. Crystal data: $\mathrm{C}_{14} \mathrm{H}_{16} \mathrm{BN}_{7} \mathrm{O}_{3} \mathrm{~S}_{3} \mathrm{~W} ; M_{\mathrm{r}}=621.19$; trigonal; $R 3 ; a=b$ $=14.2437(4) \AA ; c=17.8872(5) \AA ; V=3142.81(15) \AA^{3} ; Z=6$; $D_{\mathrm{c}}=1.969 \mathrm{Mg} \mathrm{m}^{-3} ; \mu(\mathrm{Mo} \mathrm{K \alpha})=5.843 \mathrm{~mm}^{-1} ; T=200(2) \mathrm{K}$, orange plates, $0.26 \times 0.10 \times 0.10 \mathrm{~mm} ; 3965$ independent measured reflections, $F$ refinement, R1 $=0.022,{ }^{\mathrm{wR} 2}=0.020 ; 2763$ independent observed absorption corrected reflections $(|I|>3 \sigma(|I|)$, $\left.2 \theta \leq 60^{\circ}\right), 177$ parameters, CCDC 686006. It is a crystallographic corollary of the $R 3$ space group that the carbonyls and nitrosyl ligands are disordered. In the presence of $\mathrm{W}$ it was not possible to resolve the $\mathrm{C}$ sites from the $\mathrm{N}$ sites. Consequently, $\mathrm{C}(1)$ (occupancy $2 / 3$ ) and $N(1)$ (occupancy $1 / 3$ ) are refined with identical positional and displacement parameters (NC1, Figure 1). The ellipsoids for these atoms are somewhat elongated, which is to be expected, as $\mathrm{W}-\mathrm{N}$ and $\mathrm{W}-\mathrm{C}$ distances would not be anticipated to be exactly equal. The crystal structure is isomorphous with that found previously for $\left[\operatorname{Re}(\mathrm{CO})_{3}\left\{\mathrm{HB}(\mathrm{mt})_{3}\right\}\right]{ }^{26}$ The molecular structure of $2 \cdot 2 \mathrm{THF}$ has been previously determined in the space group $P 2_{1} / c$, and while individual carbonyl and nitrosyl sites could not be crystallographically distinguished, ligand identities were assigned on the basis of metrical parameters derived from DFT studies.

Synthesis of $\left[\mathrm{Mo}(\mathrm{NO})(\mathrm{CO})_{2}\left\{\mathrm{HB}(\mathrm{mt})_{3}\right\}\right]$ (3). Method a. A mixture of $\left[\mathrm{Mo}(\mathrm{CO})_{6}\right](1.00 \mathrm{~g}, 3.79 \mathrm{mmol})$ and $\mathrm{Na}\left[\mathrm{HB}(\mathrm{mt})_{3}\right](1.42$ $\mathrm{g}, 3.79 \mathrm{mmol})$ was heated under reflux in acetonitrile $(40 \mathrm{~mL})$ for $2 \mathrm{~h}$ under a nitrogen atmosphere, after which time the appearance changed from a white suspension to an orange solution. The mixture was cooled to room temperature, and Diazald $(0.81 \mathrm{~g}, 3.79 \mathrm{mmol})$ was added. The mixture was stirred for $3 \mathrm{~h}$, during which time an orange crystalline solid precipitated out. Stirring was stopped, the orange solid was allowed to settle, and the mother liquor was decanted from the solid. The remaining solid was washed with diethyl ether $(2 \times 40 \mathrm{~mL})$ and dried in air. The product was recrystallized from $\mathrm{CH}_{2} \mathrm{Cl}_{2}$ and ethanol. Yield: $0.92 \mathrm{~g}(46 \%)$.

Method b. A sample of $\left[\mathrm{Mo}\left(\eta^{3}-\mathrm{C}_{3} \mathrm{H}_{5}\right)(\mathrm{CO})_{2}\left\{\mathrm{HB}(\mathrm{mt})_{3}\right\}\right]$ (4; $0.213 \mathrm{~g}, 0.42 \mathrm{mmol}$ ) was slurried in 1,2-dimethoxyethane and then treated with excess $[\mathrm{NO}] \mathrm{BF}_{4}(0.049 \mathrm{~g}, 5.8 \mathrm{mmol})$. The slurry was warmed slowly to room temperature with stirring, followed by removal of the solvent in vacuo. The residue was extracted with dichloromethane $(2 \times 10 \mathrm{~mL})$ and the combined extracts filtered through diatomaceous earth. The filtrate was concentrated to $2 \mathrm{~mL}$ and then diluted with hexane to complete precipitation of the product. Yield: $0.11 \mathrm{~g}(52 \%)$.

Method c. A suspension of $\left[\mathrm{Mo}(\mathrm{CO})_{6}\right](3.467 \mathrm{~g}, 13.13 \mathrm{mmol})$ in acetonitrile was heated under reflux for $15 \mathrm{~h}$ and then cooled to room temperature and treated with $\mathrm{Na}\left[\mathrm{HB}(\mathrm{mt})_{3}\right](5.15 \mathrm{~g}, 15.2$ mmol). The mixture was stirred for $1 \mathrm{~h}$ and then cooled (dry ice/ propanone), treated with solid [NO]BF 4 (1.573 g, $13.4 \mathrm{mmol})$, and warmed slowly to room temperature. The solvent was removed in vacuo and the residue crystallized from a mixture of dichloromethane and hexane. Yield: $3.67 \mathrm{~g}(56 \%)$.

Method d. A solution of $\mathrm{Na}\left[\mathrm{Mo}(\mathrm{CO})_{3}\left\{\mathrm{HB}(\mathrm{mt})_{3}\right\}\right](1.39 \mathrm{~g}, 2.69$ $\mathrm{mmol})^{9 \mathrm{a}}$ in THF $(40 \mathrm{~mL})$ was treated with $n$-butyl nitrite $(3.0 \mathrm{~mL}$, $\left.0.88 \mathrm{~g} \mathrm{~mL}^{-1}, 4.80 \mathrm{mmol}\right)$ and then heated under reflux for $10 \mathrm{~min}$. After it was cooled, the solution was diluted with water $(100 \mathrm{~mL})$ and then extracted with dichloromethane $(2 \times 100 \mathrm{~mL})$. The extracts were combined, dried over sodium sulfate, and then concentrated with the addition of hexane to provide the title compound. Yield: $0.71 \mathrm{~g}(53 \%)$. IR (Nujol): 2472, $2446 v(\mathrm{BH}), 1992,1895 v(\mathrm{CO})$, $1628 v(\mathrm{NO}) \mathrm{cm}^{-1}$. IR $\left(\mathrm{CH}_{2} \mathrm{Cl}_{2}\right): 2416 v(\mathrm{BH}), 2007,1915 v(\mathrm{CO})$, $1636 v(\mathrm{NO}) \mathrm{cm}^{-1}$. IR (THF): 1999, $1909 v(\mathrm{CO}), 1644 v(\mathrm{NO})$ $\mathrm{cm}^{-1}$. IR (MeCN): 2003, $1910 v(\mathrm{CO}), 1635 v(\mathrm{NO}) \mathrm{cm}^{-1}$. The previous report ${ }^{11}$ of the synthesis of $\mathbf{2}$ and $\mathbf{3}$ included the observation that the observed and calculated relative infrared intensities were inconsistent; calculations predicted relative intensities for $v_{\mathrm{s}}(\mathrm{CO}), v_{\mathrm{as}}(\mathrm{CO})$, and $v(\mathrm{NO})$ of 2 in the ratio 1:1.15:1.10, while the experimentally determined $v(\mathrm{NO})$ was approximately twice that of the $\mathrm{v}(\mathrm{CO})$ intensities. We find that in dichloromethane (absorbance mode) the relative intensities are 1:1.18:0.73: i.e., that the nitrosyl peak is actually the least intense but the ratio is essentially comparable to that which was calculated. A similar pattern of intensities was observed for 3 (Figure S4, Supporting Information). ${ }^{1} \mathrm{H} \mathrm{NMR}\left(25{ }^{\circ} \mathrm{C}, \mathrm{CD}_{2} \mathrm{Cl}_{2}\right): \delta_{\mathrm{H}} 3.57,3.65,3.68(\mathrm{~s} \times$ $\left.3,3 \mathrm{H} \times 3, \mathrm{NCH}_{3}\right), 6.80,6.84,6.86,6.87,6.89,6.90\left(\mathrm{~d} \times 6,{ }^{3} J_{\mathrm{HH}}\right.$ $=2 \mathrm{~Hz}, 1 \mathrm{H} \times 6, \mathrm{NHC}=\mathrm{CHN}) \mathrm{ppm} .{ }^{1} \mathrm{H} \mathrm{NMR}\left(\mathrm{CDCl}_{3},-45^{\circ} \mathrm{C}\right.$, $500.04 \mathrm{MHz}): \delta_{\mathrm{H}} 3.62,3.71,3.74\left(\mathrm{~s} \times 3,3 \mathrm{H} \times 3, \mathrm{NCH}_{3}\right), 6.81$, $6.86,6.89,6.90,6.92,6.94\left(\mathrm{~d} \times 6,1 \mathrm{H} \times 6,{ }^{3} J_{\mathrm{HH}}=2.0 \mathrm{~Hz}\right)$. The chemical shifts of the $\mathrm{NCH}_{3}$ resonances are invariant within experimental precision over the temperature range $228-294 \mathrm{~K} .{ }^{1} \mathrm{H}$ NMR $\left(d_{8}\right.$-toluene, $\left.500.04 \mathrm{MHz}, 183 \mathrm{~K}\right): \delta_{\mathrm{H}} 3.24,3.40,3.45(\mathrm{~s} \times$ $\left.3,3 \mathrm{H} \times 3, \mathrm{NCH}_{3}\right), 6.14,6.16,6.21,6.94,6.95,7.02(\mathrm{~d}$ br $\times 6,1$ $\left.\mathrm{H} \times 6,{ }^{2} J_{\mathrm{HH}}=2 \mathrm{~Hz}\right) .{ }^{1} \mathrm{H} \mathrm{NMR}\left(d_{8}\right.$-toluene, $\left.500.04 \mathrm{MHz}, 95^{\circ} \mathrm{C}\right)$ : $\delta_{\mathrm{H}} 3.04,3.17,3.19$ (s.br $\left.\times 3,3 \mathrm{H} \times 3, \mathrm{NCH}_{3}\right), 6.00(\mathrm{~s}$ br, $2 \mathrm{H})$, $6.08,6.40,6.44,6.47(\mathrm{~s} \mathrm{br} \times 4,1 \mathrm{H} \times 4, \mathrm{NCH}=\mathrm{CHN})$. N.B.: the "coalescence" temperature is not quite reached at $368 \mathrm{~K}$, the practical safe temperature limit for $d_{8}$-toluene (Figure S5, Supporting Information; see the Results and Discussion). $\Delta G^{\ddagger}(368 \mathrm{~K}) \approx 75$ $\mathrm{kJmol}^{-1} \cdot{ }^{13} \mathrm{C}\left\{{ }^{1} \mathrm{H}\right\}$ NMR $\left(25^{\circ} \mathrm{C}, \mathrm{CD}_{2} \mathrm{Cl}_{2}\right): \delta_{\mathrm{C}} 226.9,222.5(\mathrm{MoCO})$, $158.4,156.3,155.3(\mathrm{C}=\mathrm{S}) 123.2$ (1C), 122.8 (2C), 120.2 (1C), $119.9(2 \mathrm{C})(\mathrm{NHC}=\mathrm{CHN}), 35.12(1 \mathrm{C}), 34.77(2 \mathrm{C})\left(\mathrm{NCH}_{3}\right) \mathrm{ppm}$. ${ }^{11} \mathrm{~B}\left\{{ }^{1} \mathrm{H}\right\}$ NMR: $\delta_{\mathrm{B}}-2.56$. APCI-MS: $m / z(\%) 535(5)[\mathrm{M}]^{+}, 477$ (100) $\left[\mathrm{M}-\mathrm{CO}-\mathrm{NO}^{+}\right.$. FAB-MS: $m / z$ (\%) $535(7)[\mathrm{M}]^{+}, 507$ (12) $[\mathrm{M}-\mathrm{CO}]^{+}, 479(15)[\mathrm{M}-2 \mathrm{CO}]^{+}, 449$ (4) $[\mathrm{M}-2 \mathrm{CO}-$ $\mathrm{NO}^{+}$. Anal. Found: C, 31.39; H, 3.11; N, 18.19. Calcd for $\mathrm{C}_{14} \mathrm{H}_{16} \mathrm{BMoN}_{7} \mathrm{O}_{3} \mathrm{~S}_{3}$ : C, 31.53; H, 3.02; N, 18.39.

Synthesis of $\left[\mathrm{Mo}(\mathrm{CO})_{2}\left(\eta^{3}-\mathrm{C}_{3} \mathrm{H}_{5}\right)\left\{\mathrm{HB}(\mathrm{mt})_{3}\right\}\right]$ (4). A mixture of $\left[\mathrm{MoCl}\left(\eta^{3}-\mathrm{C}_{3} \mathrm{H}_{5}\right)(\mathrm{NCMe})_{2}(\mathrm{CO})_{2}\right]^{30}(0.285 \mathrm{~g}, 0.92 \mathrm{mmol})$ and $\mathrm{Na}[\mathrm{H}-$ $\mathrm{B}(\mathrm{mt})_{3}$ ] $(0.390 \mathrm{~g}, 0.99 \mathrm{mmol})$ in THF $(30 \mathrm{~mL})$ was stirred for $15 \mathrm{~min}$. The completion of the reaction was indicated by the replacement of infrared bands due to the starting material (THF: 1946, $1852 \mathrm{~cm}^{-1}$ ) by those of the product $\left(1930,1844 \mathrm{~cm}^{-1}\right)$. The solvent was removed in vacuo and the residue extracted with dichloromethane $(2 \times 15 \mathrm{~mL})$. The combined extracts were filtered through diatomaceous earth, concentrated to ca. $10 \mathrm{~mL}$, and then diluted with hexane $(10 \mathrm{~mL})$. The mixture was cooled overnight $\left(-16^{\circ} \mathrm{C}\right)$ to provide orange crystals. Yield: $0.406 \mathrm{~g}$ (87\%). IR (Nujol): $2453 v(\mathrm{BH}), 1926,1825 v(\mathrm{CO})$, $1561 \mathrm{w}, 1461 \mathrm{~s}, 1207 \mathrm{~s}, 1089 \mathrm{w} \mathrm{cm}^{-1}$. IR (THF): $1930,1844 \mathrm{~cm}^{-1}$. IR $\left(\mathrm{CH}_{2} \mathrm{Cl}_{2}\right): 1927,1834 \mathrm{~cm}^{-1}$.. Anal. Found: C, 36.61; H, 3.76; N, 15.29. Calcd for $\mathrm{C}_{17} \mathrm{H}_{21} \mathrm{BMoN}_{6} \mathrm{O}_{3} \mathrm{~S}_{3}: \mathrm{C}, 36.44 ; \mathrm{H}, 3.78 ; \mathrm{N}, 15.00 .{ }^{1} \mathrm{H}$ NMR data corresponded to those already reported, ${ }^{16}$ to which may be added the following data: ${ }^{13} \mathrm{C}\left\{{ }^{1} \mathrm{H}\right\} \mathrm{NMR}\left(\mathrm{CDCl}_{3}, 25^{\circ} \mathrm{C}\right): \delta_{\mathrm{C}} 226.1$ (MoCO), 160.2 (CS), 122.6, 119.6 (NCHCHN), $68.9\left(\mathrm{H}_{2} \mathrm{CCHCH}_{2}\right)$, 59.0, $55.2\left(\mathrm{H}_{2} \mathrm{CCHCH}_{2}\right), 34.74\left(\mathrm{NCH}_{3}\right) .{ }^{11} \mathrm{~B}\left\{{ }^{1} \mathrm{H}\right\} \mathrm{NMR}\left(\mathrm{CDCl}_{3}, 25\right.$ 
$\left.{ }^{\circ} \mathrm{C}\right): \delta_{\mathrm{B}}-2.12$. FAB-MS (nba matrix): $\mathrm{m} / z(\%) 546(25)[\mathrm{M}]^{+}, 518$ (33) $[\mathrm{M}-\mathrm{CO}]^{+}, 490(72)[\mathrm{M}-2 \mathrm{CO}]^{+}, 449(91)\left[\mathrm{Mo}\left\{\mathrm{HB}(\mathrm{mt})_{3}\right\}\right]$.

Synthesis of [Mo(NO) $\left.(\mathrm{CO})_{2}\left\{\mathrm{H}_{2} \mathrm{~B}(\mathrm{mt})_{2}\right\}\right]$ (5). A mixture of [Mo$\left.(\mathrm{CO})_{6}\right](1.00 \mathrm{~g}, 3.79 \mathrm{mmol})$ and $\mathrm{Na}\left[\mathrm{H}_{2} \mathrm{~B}(\mathrm{mt})_{2}\right](0.99 \mathrm{~g}, 3.79 \mathrm{mmol})$ was heated under reflux in acetonitrile $(40 \mathrm{~mL})$ for $12 \mathrm{~h}$ under a nitrogen atmosphere, during which time the color had changed from a white suspension to an orange solution. The reaction mixture was cooled to room temperature, and then Diazald $(0.81 \mathrm{~g}, 3.79 \mathrm{mmol})$ was added. The mixture was stirred for $3 \mathrm{~h}$, during which time an orange crystalline solid precipitated out. The solvent volume was reduced to a minimum, and the reaction mixture was left overnight at $-16{ }^{\circ} \mathrm{C}$ for further precipitation of the product. The mother liquor was decanted off the solid. The remaining solid was washed with diethyl ether $(2 \times 40 \mathrm{~mL})$ and dried in air. The product was recrystallized from $\mathrm{CH}_{2} \mathrm{Cl}_{2}$ and hexane. Yield: $1.28 \mathrm{~g}$ (81\%). IR (Nujol): $2460 v(\mathrm{BH}), 2232 v(\mathrm{BHMo}), 2016,1927 v(\mathrm{CO}), 1662 v(\mathrm{NO})$ $\mathrm{cm}^{-1}$. IR $\left(\mathrm{CH}_{2} \mathrm{Cl}_{2}\right): 2435 v(\mathrm{BH}), 2233 v(\mathrm{BHMo}), 2028,1945 v(\mathrm{CO})$, $1661 v(\mathrm{NO}) \mathrm{cm}^{-1} .{ }^{1} \mathrm{H}$ NMR $\left(25^{\circ} \mathrm{C}, \mathrm{CD}_{2} \mathrm{Cl}_{2}\right): \delta_{\mathrm{H}}-3.80(\mathrm{~d} \mathrm{br}, 1 \mathrm{H}$, BHMo), 3.48 (s, $\left.3 \mathrm{H}, \mathrm{NCH}_{3}\right), 3.56$ (s, $\left.3 \mathrm{H}, \mathrm{NCH}_{3}\right), 6.79,6.80$ (d, $\left.{ }^{3} J_{\mathrm{HH}}=2.3 \mathrm{~Hz}, 2 \mathrm{H}, \mathrm{NHC}=\mathrm{CHN}\right), 6.83,6.84\left(\mathrm{~d},{ }^{3} J_{\mathrm{HH}}=1.9 \mathrm{~Hz}, 2 \mathrm{H}\right.$, $\mathrm{NHC}=\mathrm{CHN}) \mathrm{ppm} .{ }^{13} \mathrm{C}\left\{{ }^{1} \mathrm{H}\right\} \mathrm{NMR}\left(25^{\circ} \mathrm{C}, \mathrm{CD}_{2} \mathrm{Cl}_{2}\right): \delta_{\mathrm{C}} 216.7,224.3$ (MoCO), 159.6, $163.2(\mathrm{C}=\mathrm{S}), 122.1,122.3,122.6,122.9(\mathrm{NHC}=\mathrm{CHN})$, $35.2\left(\mathrm{NCH}_{3}\right)$ ppm. Anal. Found: C, 29.01; H, 2.65; N, 17.11. Calcd for $\mathrm{C}_{10} \mathrm{H}_{12} \mathrm{BMoN}_{5} \mathrm{O}_{3} \mathrm{~S}_{2}$ : C, 28.52; $\mathrm{H}, 2.87 ; \mathrm{N}, 16.63$. Crystals of the hemisolvate $\mathbf{5} \cdot 0.5 \mathrm{EtOH}$ suitable for diffractometry were grown by slow diffusion of ethanol into a saturated solution of $\mathbf{2}$ in dichloromethane. Crystal data: $\mathrm{C}_{10} \mathrm{H}_{12} \mathrm{BMoN}_{5} \mathrm{O}_{3} \mathrm{~S}_{2} \cdot 0.5 \mathrm{C}_{2} \mathrm{H}_{6} \mathrm{O} ; M_{\mathrm{r}}=444.15$; orthorhombic; Pnnm; $a=17.4413(6) \AA ; b=6.7479(2) \AA ; c=$ 15.0143(6) $\AA ; V=1767.07(11) \AA^{3} ; Z=4 ; D_{\mathrm{c}}=1.669 \mathrm{Mg} \mathrm{m}^{-3}$; $\mu(\mathrm{Mo} \mathrm{K} \alpha)=1.00 \mathrm{~mm}^{-1} ; T=200(2) \mathrm{K}$, orange prism, $0.31 \times 0.20$ $\times 0.031 \mathrm{~mm} ; 20383$ measured reflections, $F$ refinement, R1 $=0.033$, $\mathrm{wR} 2=0.038 ; 1227$ independent observed absorption-corrected reflections $\left(|I|>2 \sigma(|I|), 2 \theta \leq 55^{\circ}\right), 126$ parameters, CCDC 686008 . Spectroscopic data indicate that the site trans to the $\mathrm{BH}_{2}$ group is exclusively occupied by a carbonyl ligand and that two nonsulfur cis sites are occupied by a carbonyl and a nitrosyl ligand. Consequently, within this structure, where the molecule lies on a crystallographic mirror plane, these cis sites represent a crystallographically requisite 1:1 disorder of nitrosyl and carbonyl. It was not possible to resolve the $\mathrm{C}$ sites from the $\mathrm{N}$ sites; thus, $\mathrm{C}(2)$ (occupancy $1 / 2$ ) and $\mathrm{N}(2)$ (occupancy $1 / 2$ ) are refined with identical positional and displacement parameters $(=\mathrm{NC} 1$; Figure 2$)$. The ellipsoids for these atoms are somewhat elongated, which is to be expected, as $\mathrm{Mo}-\mathrm{N}$ and $\mathrm{Mo}-\mathrm{C}$ distances would not be anticipated to be exactly equal.

Synthesis of $\left[\mathrm{W}(\mathrm{NO})(\mathrm{CO})_{2}\left\{\mathrm{H}_{2} \mathrm{~B}(\mathrm{mt})_{2}\right\}\right]$ (7). A mixture of $\left[\mathrm{W}(\mathrm{CO})_{3}(\mathrm{NCMe})_{3}\right](0.10 \mathrm{~g}, 0.26 \mathrm{mmol})$ and $\mathrm{Na}\left[\mathrm{H}_{2} \mathrm{~B}(\mathrm{mt})_{2}\right](0.07 \mathrm{~g}$, $0.26 \mathrm{mmol})$ was stirred in acetonitrile $(10 \mathrm{~mL})$ at room temperature for $1 \mathrm{~h}$ and Diazald $(0.05 \mathrm{~g}, 0.26 \mathrm{mmol})$ added to provide an orange suspension. The solvent was removed in vacuo and the residue extracted into $\mathrm{CH}_{2} \mathrm{Cl}_{2}(10 \mathrm{~mL})$, filtered through diatomaceous earth, and then diluted with hexane $(5 \mathrm{~mL})$. Slow concentration of the solution to ca. $5 \mathrm{~mL}$ and storage at $-16{ }^{\circ} \mathrm{C}$ resulted in the formation of orange crystals of the product. The product was filtered off, washed with hexane $(10 \mathrm{~mL})$ and diethyl ether $(2 \times 5 \mathrm{~mL})$, and dried in vacuo. Yield: $0.09 \mathrm{~g}(64 \%)$. IR (Nujol): $2406 v(\mathrm{BH}), 2260 v(\mathrm{BHW}), 2012$, $1915 v(\mathrm{CO}), 1639 v(\mathrm{NO}) \mathrm{cm}^{-1}$. IR $\left(\mathrm{CH}_{2} \mathrm{Cl}_{2}\right): 2417 v(\mathrm{BH}), 2228$ $v(\mathrm{BHW}), 1994,1901 v(\mathrm{CO}), 1642 v(\mathrm{NO}) \mathrm{cm}^{-1} .{ }^{1} \mathrm{H}$ NMR $\left(25^{\circ} \mathrm{C}\right.$, $\left.\mathrm{CD}_{2} \mathrm{Cl}_{2}\right): \delta_{\mathrm{H}}-3.16(\mathrm{br}, 1 \mathrm{H}, \mathrm{B}-\mathrm{H}-\mathrm{W}), 3.32\left(\mathrm{~s}, 3 \mathrm{H}, \mathrm{NCH}_{3}\right), 3.38$ (s, $\left.3 \mathrm{H}, \mathrm{NCH}_{3}\right), 7.16,7.19\left(\mathrm{~d} \times 2,{ }^{3} \mathrm{~J}_{\mathrm{HH}}=2.0,2 \mathrm{H}, \mathrm{NHC}=\mathrm{CHN}\right), 7.43$, $7.46\left(\mathrm{~d},{ }^{3} J_{\mathrm{HH}}=1.8 \mathrm{~Hz}, 2 \mathrm{H}, \mathrm{NHC}=\mathrm{CHN}\right) \mathrm{ppm}$. Anal. Found: $\mathrm{C}$,
23.98; H, 2.73; N, 14.14. Calcd for $\mathrm{C}_{10} \mathrm{H}_{12} \mathrm{BN}_{5} \mathrm{O}_{3} \mathrm{~S}_{2} \mathrm{~W}$ : C, 23.60; $\mathrm{H}$, 2.38; N, 13.76 .

Synthesis of $\left[\mathrm{W}(\mathrm{NO})(\mathrm{CO})_{2}\left(\mathrm{PPh}_{3}\right)\left\{\mathrm{H}_{2} \mathrm{~B}(\mathrm{mt})_{2}\right\}\right](8)$. A mixture of trans, mer- $\left[\mathrm{W}(\mathrm{NO})(\mathrm{CO})_{3}\left(\mathrm{PPh}_{3}\right)_{2}\right]\left[\mathrm{PF}_{6}\right]^{12}\left(\mathbf{1}-\mathbf{P F}_{\mathbf{6}} ; 0.52 \mathrm{~g}, 0.52 \mathrm{mmol}\right)$ and $\mathrm{Na}\left[\mathrm{H}_{2} \mathrm{~B}(\mathrm{mt})_{2}\right](0.12 \mathrm{~g}, 0.52 \mathrm{mmol})$ was stirred in $\mathrm{CH}_{2} \mathrm{Cl}_{2}(60 \mathrm{~mL})$ at room temperature for $24 \mathrm{~h}$. A color change from bright yellow to orange was observed. The orange solution was filtered through diatomaceous earth and the solvent volume reduced to half (ca. 30 $\mathrm{mL}$ ) and then diluted with ethanol $(30 \mathrm{~mL})$. The solvent volume was further reduced slowly (rotary evaporator) to furnish a bright orange microcrystalline product. The product was filtered off, washed with ethanol $(2 \times 20 \mathrm{~mL})$, and dried in vacuo. Yield: $0.28 \mathrm{~g}(70 \%)$. IR (Nujol): $2408 v(\mathrm{BH}), 1997,1894 v(\mathrm{CO}), 1624 v(\mathrm{NO}) \mathrm{cm}^{-1}$. IR $\left(\mathrm{CH}_{2} \mathrm{Cl}_{2}\right): 2415 v(\mathrm{BH}), 2013,1922 v(\mathrm{CO}), 1636 v(\mathrm{NO}) \mathrm{cm}^{-1} . \mathrm{IR}$ (THF): 2004, $1922 v(\mathrm{CO}), 1627 v(\mathrm{NO}) \mathrm{cm}^{-1} .{ }^{1} \mathrm{H}$ NMR $\left(25{ }^{\circ} \mathrm{C}\right.$, $\left.\mathrm{CD}_{2} \mathrm{Cl}_{2}\right): \delta_{\mathrm{H}} 3.62,3.73\left(\mathrm{~s} \times 2,3 \mathrm{H} \times 2, \mathrm{NCH}_{3}\right), 6.79,6.86(\mathrm{~d} \times 2$, $\left.{ }^{3} J_{\mathrm{HH}}=2.1,2 \mathrm{H}, \mathrm{HC}=\mathrm{CH}\right), 6.92,7.01\left(\mathrm{~d},{ }^{3} J_{\mathrm{HH}}=1.8 \mathrm{~Hz}, 2 \mathrm{H}\right.$, $\mathrm{HC}=\mathrm{CH}), 7.14-7.23\left(\mathrm{~m}, 15 \mathrm{H}, \mathrm{C}_{6} \mathrm{H}_{5}\right) \mathrm{ppm} .{ }^{13} \mathrm{C}\left\{{ }^{1} \mathrm{H}\right\}$ NMR $\left(25{ }^{\circ} \mathrm{C}\right.$, $\mathrm{CD}_{2} \mathrm{Cl}_{2}$ ): $\delta_{\mathrm{C}} 215.1$ (WCO), $211.5\left(\mathrm{~d},{ }^{2} J_{\mathrm{PC}}=45.6 \mathrm{~Hz}, \mathrm{WCO}\right), 161.3$, $156.4(\mathrm{C}=\mathrm{S}) 125.2,124.4,120.0,119.3(\mathrm{HC}=\mathrm{CH}), 35.50,35.31$ $\left(\mathrm{NCH}_{3}\right)$ ppm. ${ }^{31} \mathrm{P}\left\{{ }^{1} \mathrm{H}\right\}$ NMR $\left(25^{\circ} \mathrm{C}, \mathrm{CDCl}_{3}\right): \delta_{\mathrm{P}} 22.4 \mathrm{ppm} .{ }^{11} \mathrm{~B}\left\{{ }^{1} \mathrm{H}\right\}$ $\left(25{ }^{\circ} \mathrm{C}, d_{6}\right.$-DMSO): $\delta_{\mathrm{B}} 3.38 \mathrm{ppm}$. APCI-MS: $m / z$ (\%) 715 (5) $[\mathrm{M}-$ $\mathrm{CO}-\mathrm{NO}]^{+}, 532.1(40)\left[\mathrm{M}-\mathrm{PPh}_{3}\right]^{+}, 450.1(5)\left[\mathrm{W}\left\{\mathrm{H}_{2} \mathrm{~B}(\mathrm{mt})_{2}\right\}\right]$. Anal. Found: $\mathrm{C}, 43.51 ; \mathrm{H}, 2.94 ; \mathrm{N}, 9.39$. Calcd for $\mathrm{C}_{28} \mathrm{H}_{27} \mathrm{BN}_{5} \mathrm{O}_{3} \mathrm{~S}_{2} \mathrm{PW}$ : C, 43.60; H, 3.53; N, 9.08. Crystal data: $\mathrm{C}_{28} \mathrm{H}_{27} \mathrm{BN}_{5} \mathrm{O}_{3} \mathrm{PS}_{2} \mathrm{~W} \cdot \mathrm{CH}_{2} \mathrm{Cl}_{2}$; $M_{\mathrm{r}}=856.25$; triclinic; $P \overline{1}$ (No. 2); $a=10.0313(4) \AA ; b=10.3673(4)$ $\AA ; c=16.8936(7) \AA \circ ; \alpha=95.5217(14)^{\circ} ; \beta=90.9341(12)^{\circ} ; c=$ 102.7447(19) ${ }^{\circ} ; \AA ; V=1704.38(12) \AA^{3} ; Z=4 ; D_{\mathrm{c}}=1.668 \mathrm{Mg} \mathrm{m}^{-3}$; $\mu(\mathrm{Mo} \mathrm{K} \alpha)=3.753 \mathrm{~mm}^{-1} ; T=200(2) \mathrm{K}$, yellow plate, $0.08 \times 0.28$ $\times 0.28 \mathrm{~mm} ; 29255$ measured reflections, $F$ refinement, $\mathrm{R} 1=0.0351$, $\mathrm{wR} 2=0.0372 ; 5587$ independent observed absorption corrected reflections $\left(|I|>3 \sigma(|I|), 2 \theta \leq 55^{\circ}\right), 403$ parameters, CCDC 686008. Spectroscopic data indicate that the site trans to the phosphine is exclusively a carbonyl group and that the two nonsulfur sites cis to the phosphine are occupied by one carbonyl and one nitrosyl. It soon became apparent that, in this structure, $\mathrm{NO}$ and $\mathrm{CO}$ were disordered over the two cis positions, though not necessarily equally. It was not possible to resolve $\mathrm{C}$ sites from the proximate $\mathrm{N}$ sites; thus, $\mathrm{C}(2)$ and $\mathrm{N}(2)$ were refined with identical positional (NC2; Figure 3) and displacement parameters and likewise for $\mathrm{C}(3)$ and N(3) (NC3; Figure $3)$. The relative occupancies of the sites were refined, giving $0.68(5)$ for $\mathrm{N}(3)$ and $\mathrm{C}(2)$ and $0.32(5)$ for $\mathrm{N}(2)$ and $\mathrm{C}(3)$.

Acknowledgment. We thank the Australian Research Council (ARC) for financial support (Grant Nos. DP034270, DP0771497) and the University of Botswana for a studentship (to N.T.).

Supporting Information Available: CIF files, giving full details of the crystal structure determinations of 2 (CCDC 686006), 5 (CCDC 686007), and 8 (CCDC 686008), Table S1 (IR data), and Figure S1 (molecular geometry of $\mathbf{2}$ in a crystal (alternative view)), Figure S2 (molecular geometry of a crystal of $\mathbf{5} \cdot 0.5 \mathrm{EtOH}$ (alternative view)), Figure S3 (molecular geometry of a crystal of $\mathbf{8} \cdot \mathrm{CH}_{2} \mathrm{Cl}_{2}$ (alternative view)), Figure S4 (infrared spectrum of 3), and Figure S5 (temperature-dependent ${ }^{1} \mathrm{H}$ NMR spectra of 3). This material is available free of charge via the Internet at http://pubs.acs.org.

\section{OM800416J}

